\title{
Ore metal redistribution by hydrocarbon-brine and hydrocarbon-halide melt phases, North Range footwall of the Sudbury Igneous Complex, Ontario, Canada
}

Received: 5 October 2004 / Accepted: 10 June 2005 / Published online: 9 August 2005

(C) Springer-Verlag 2005

\begin{abstract}
We report methane-dominant hydrocarbon (fluid) inclusions $\left(\mathrm{CH}_{4} \pm \mathrm{C}_{2} \mathrm{H}_{6}-\mathrm{C}_{2} \mathrm{H}_{2}, \mathrm{C}_{3} \mathrm{H}_{8}\right)$ coexisting with primary brine inclusions and secondary halidemelt (solid $\mathrm{NaCl}$ ) inclusions in $\mathrm{Au}-\mathrm{Pt}$-rich quartz-sulfide-epidote alteration veins associated with the footwall-style $\mathrm{Cu}-\mathrm{PGE}$ (platinum-group element)-Au deposits at the Fraser Mine (North Range of the Sudbury Igneous Complex). Evidence for coentrapment of immiscible hydrocarbon-brine, and hydrocarbonhalide melt mixtures is demonstrated. A primary $\mathrm{CH}_{4}$ brine assemblage was trapped during quartz growth at relatively low $T$ (min. $T_{\text {trapping }} \sim 145-315^{\circ} \mathrm{C}$ ) and $P$ (max. $P_{\text {trapping }} \sim 500 \mathrm{bar}$ ), prior to the crystallization of sulfide minerals in the veins. Secondary inclusions contain solid halite and a mixture of $\mathrm{CH}_{4}, \mathrm{C}_{2} \mathrm{H}_{6}-\mathrm{C}_{2} \mathrm{H}_{2}$ and $\mathrm{C}_{3} \mathrm{H}_{8}$ and were trapped at a minimum $T$ of $\sim 710^{\circ} \mathrm{C}$. The halite inclusions may represent halidemelt that exsolved from crystallizing sulfide ores that texturally postdate (by replacement) early alteration quartz hosting the primary, lower $T$ brine- $\mathrm{CH}_{4}$ assemblage. Laser ablation ICP-MS analyses show that the brine, hydrocarbon and halide-melt inclusions contain significant concentrations of $\mathrm{Cu}(0.1-1 \mathrm{wt} \%$ range), $\mathrm{Au}, \mathrm{Bi}, \mathrm{Ag}$ and $\mathrm{Pt}$ (all $0.1-10 \mathrm{ppm}$ range). $\mathrm{Cu}: \mathrm{Pt}$ and $\mathrm{Cu}: \mathrm{Au}$ ratios in the inclusions are significantly (up to $4 \log$ units) lower than in the host alter-
\end{abstract}

Electronic Supplementary Material Supplementary material is available for this article at http://dx.doi.org/10.1007/s00126-0050004-z

Editorial handling: P. Lightfoot

J. J. Hanley $(\bowtie) \cdot$ J. E. Mungall · E. T. C. Spooner · C. J. Bray Department of Geology, University of Toronto,

22 Russell Street, Toronto, ON,

Canada M5S 3B1

E-mail: hanley@geology.utoronto.ca

Tel.: + 1-416-9260857

Fax: + 1-416-9783938

T. Pettke

Isotope Geology and Mineral Resources, ETH Zürich, ETH Zentrum NO, 8092 Zürich, Switzerland ation veins and adjacent massive sulfide ore veins, suggesting either (1) early $\mathrm{Cu}$ loss from the volatiles by chalcopyrite precipitation or (2) enhanced $\mathrm{Au}$ and $\mathrm{Pt}$ solubilities relative to $\mathrm{Cu}$ at the temperatures of entrapment. Concentration ratios between coexisting brine and $\mathrm{CH}_{4}$ inclusions $\left[C_{\text {brine }}^{\text {elem }} / C_{\mathrm{CH}_{4}}^{\text {elem }}\right]$ are lower for $\mathrm{Cu}, \mathrm{Au}, \mathrm{Bi}$ and $\mathrm{Ag}$ than for other elements $(\mathrm{Na}, \mathrm{Ca}$, $\mathrm{Fe}, \mathrm{Mn}, \mathrm{Zn}, \mathrm{Pb}$ ) indicating that during interaction with the brine, the hydrocarbon phase was enriched in ore metals. The high concentrations of ore metals in hydrocarbon, brine and halide-melt phases confirm that both aqueous and non-aqueous volatiles were carriers of precious metals in the Sudbury environment over a wide range of temperatures. Volatile evolution and magmatic sulfide differentiation were clearly part of a single, continuous process in the Sudbury footwall. The exsolution of $\mathrm{H}_{2} \mathrm{O}$-poor volatiles from fractionated sulfide liquid may have been a principal mechanism controlling the final distribution of PGE and $\mathrm{Au}$ in the footwall ore systems. The study reports the first measurements of precious metal concentrations in fluid inclusions from a magmatic $\mathrm{Ni}-\mathrm{Cu}-\mathrm{PGE}$ environment (the Sudbury district).

Keywords Hydrocarbons · Magmatic sulfide $\cdot$ Platinum-group elements $\cdot$ Gold $\cdot$ Brines

\section{Introduction}

The segregation of ore metals (e.g., $\mathrm{Cu}, \mathrm{Au}$ ) into an aqueous-carbonic vapor phase that separates from boiling $\mathrm{NaCl}$-rich magmatic fluid been documented in many porphyry $\mathrm{Cu}-\mathrm{Au}$ systems (Heinrich et al. 1992; Mavrogenes et al. 2002; Ulrich et al. 2001). Selective partitioning of $\mathrm{Au}$ and $\mathrm{Cu}$ into the lower density fluid phase may be facilitated by the volatilization of sulfidebearing [e.g., $\mathrm{Au}(\mathrm{HS})_{2}^{-}$] rather than chloride-bearing complexes (Renders and Seward 1989; Hemley et al. 1992; Heinrich et al. 1999; Mountain and Seward 1999). Fluid inclusion evidence from unconformity-related $\mathrm{U}$ 
deposits (Ypma and Fuzikawa 1980), REE-bearing peralkaline granites (Salvi and Williams-Jones 1992), mafic-ultramafic layered intrusions (Ballhaus and Stumpfl 1986) and high-grade calcareous metasediments (Sisson et al. 1981) confirm that aqueous-carbonic fluid immiscibility can occur over a wide range of geological $P-T$ conditions. Additionally, aqueous-carbonic fluid immiscibility has been recognized as an important mechanism for $\mathrm{Au}$ deposition in Archean to Cenozoic vein Au systems (Naden and Shepherd 1989; Pettke et al. 2000). However, direct evidence for ore metal partitioning preferentially into the low-density fluid phase has not been documented in systems other than $\mathrm{Cu}-\mathrm{Au}$ porphyry deposits.

In this study, we (1) describe previously unreported hydrocarbon fluid inclusions coexisting immiscibly with primary brine inclusions and secondary halide-melt inclusions in quartz from $\mathrm{Au}$-PGE-rich quartz-sulfideepidote alteration veins associated with footwall $\mathrm{Cu}-\mathrm{Ni}-$ platinum-group element (PGE) ore deposits at the Fra- ser Mine near Sudbury, Ontario and (2) demonstrate that hydrocarbon, brine and halide-melt phases segregated significant amounts of $\mathrm{Cu}$ and precious metals. Consequently, these volatile phases must be considered important agents for metal redistribution in the Sudbury footwall. This study presents the first in-situ measurements of precious metal concentrations in volatilebearing inclusions from a magmatic $\mathrm{Ni}-\mathrm{Cu}-\mathrm{PGE}$ environment.

\section{Geological setting}

Sulfide deposits at the Fraser Mine (Falconbridge Ltd.) occur along the northern margin of the Sudbury Igneous Complex (SIC) (Fig. 1a, b). The SIC is a large, differentiated, hypabyssal igneous body composed of noritic to gabbroic cumulates overlain by residual granophyre. The SIC was produced by meteorite impact-induced melting of carbonaceous shale and lower crustal rocks at
Fig. 1 Geological setting of the footwall-style $\mathrm{Cu}-\mathrm{PGE}$ ores and associated alteration veins at the Fraser Mine

(Falconbridge Ltd.). a

Generalized regional geology and location of the Fraser Mine on the North Range of the Sudbury Igneous Complex (SIC), Ontario, Canada. b Plan view of contact-style $(\mathrm{Ni})$ ore bodies (hosted in footwall breccia at the base of the SIC) and footwall-style $\mathrm{Cu}-\mathrm{PGE}$ ore bodies (hosted in Sudbury Breccia within the gneissic footwall; cross-cuts at the Fraser Mine projected to the $762 \mathrm{~m}$ (25) level. The study area comprises the deeper footwall ore zones 37-39. c Enlarged area from Fig. 1b showing a drift layout (plan-view) of a footwall-style sulfide vein network hosted in Sudbury Breccia. d Enlargement of the tip of one of the sulfide veins showing the location of quartzsulfide-epidote veins in their typical setting. The quartzsulfide-epidote veins occur as splays or bifurcations off the main sulfide vein
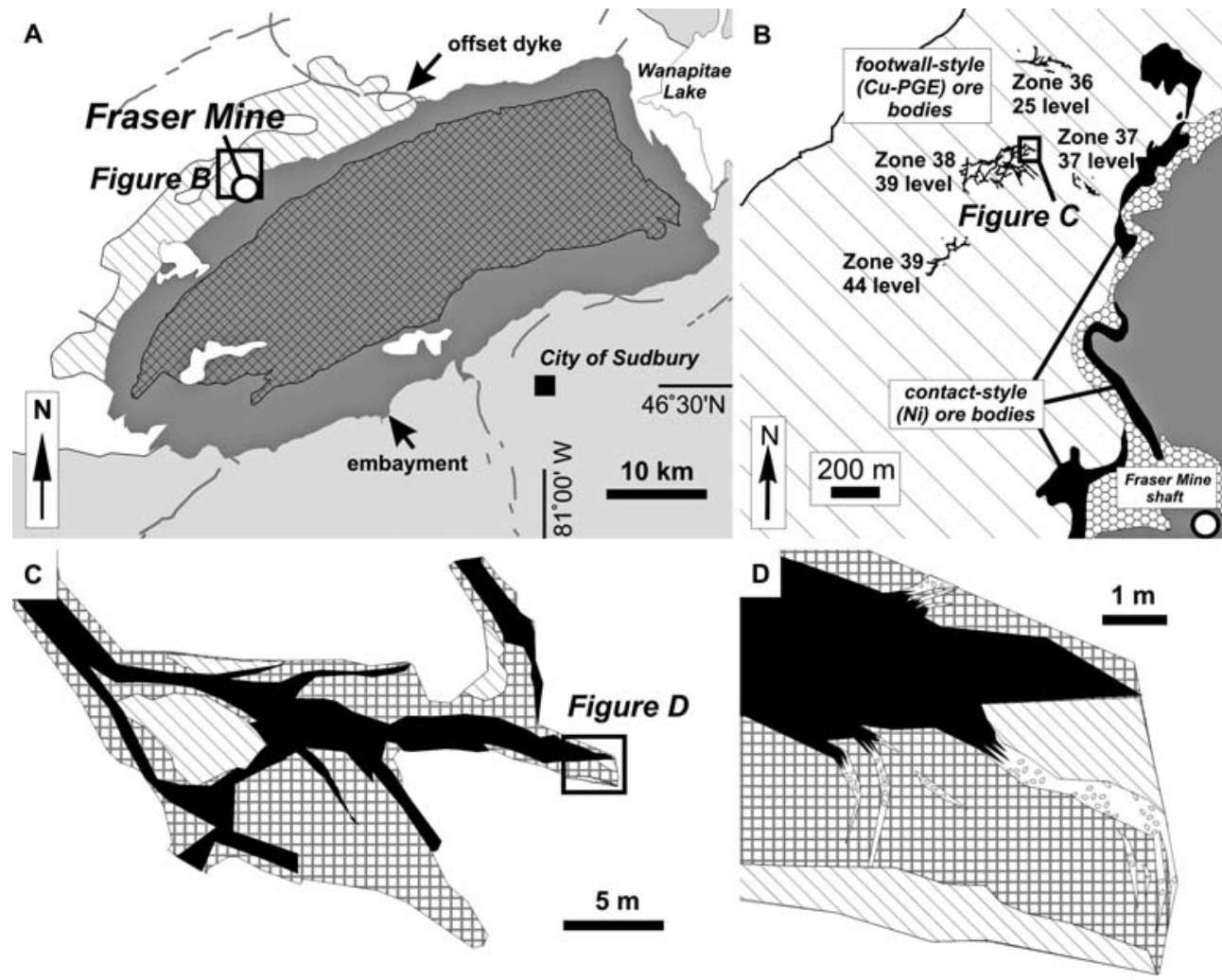

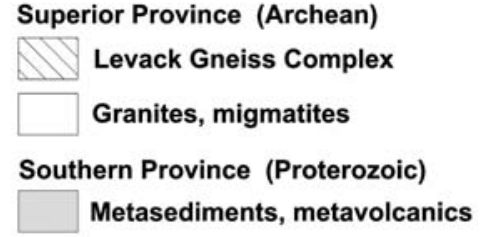

geological contacts/drift outline
Sudbury Event (mid-Proterozoic; $1850 \mathrm{Ma}$ ) Sudbury Igneous Complex (unsubdivided) ore bodies (footwall- or contact-style) footwall breccia (melted/deformed country rocks) \#冊 Sudbury Breccia (brecciated country rocks) quartz-sulfide-epidote veins (this study)

Whitewater Group (basin fill, lower Proterozoic) 
1,850 $\pm 1 \mathrm{Ma}$ (Dietz 1964; Krogh et al. 1984; Grieve 1994; Mungall et al. 2004). At the Fraser Mine, the SIC overlies partially molten and plastically deformed target rocks ("footwall breccia"; Greenman 1970). The footwall breccia overlies impact-brecciated, contact-metamorphosed Archean rocks of the Superior province (the Levack Gneiss complex; Coats and Snajdr 1984; Dressler 1984; Farrow 1994).

There are three major (widely distributed) magmatic sulfide deposit types associated with the SIC (cf. Farrow and Lightfoot 2002): (1) contact-style deposits (high Ni, low PGE) occurring at the base of the SIC within footwall breccia or a basal igneous unit ("sublayer") of the SIC; (2) offset-type deposits hosted in radial or concentric quartz diorite "offset" dykes that are physically connected to the main igneous mass of the SIC (Fig. 1a); and (3) footwall-style deposits (high $\mathrm{Cu}$, high PGE), hosted entirely within zones of Sudbury Breccia in the footwall rocks. At the Fraser mine, contact-style and footwall-style deposits occur within a structurally complex depression or "embayment" in the footwall (Fig. 1a, b; Morrison et al. 1994). Mineralized embayments are common along the northern and southern margins of the SIC. Contactstyle mineralization was introduced into the embayments along the lower contact of the SIC during sulfide saturation and differentiation of the SIC magma. The contact-style deposits consist of lenses or blocks of sulfide-rich footwall breccia. Sulfides comprise the matrix of the footwall breccia and consist of disseminated to massive pyrrotite-pentlandite-chalcopyrite with minor magnetite and pyrite. The $\mathrm{Cu} / \mathrm{Ni}$ ratio of contact-style ores are $<1 ; \mathrm{Pt}, \mathrm{Pd}$ and $\mathrm{Au}$ contents are generally low but may increase locally up to several $\mathrm{g} / \mathrm{t}$, and towards the footwall contact (Naldrett and Pessaran 1992). The contact-style deposits have a accepted magmatic origin.

The footwall-style deposits are widely distributed and occur up to $2 \mathrm{~km}$ from the SIC-footwall contact in zones of Sudbury Breccia within the Levack Gneiss Complex (Fig. 1b, c). They comprise veins (up to $1.5 \mathrm{~m}$ thick) of massive chalcopyrite-cubanite ( $\mathrm{Cu}$ content up to $27 \mathrm{wt} \%$ ) with minor pentlandite, millerite, bornite and magnetite. Footwall-style deposits are small in comparison to contact deposits but have considerable value owing to their high $\mathrm{Cu}, \mathrm{Pt}, \mathrm{Pd}$ and $\mathrm{Au}$ contents. Unlike the contact-style ores, the origin of the footwallstyle deposits is controversial. In the magmatic hypothesis, magmatic differentiation of sulfide liquid at the lower contact of the SIC resulted in the formation of a residual sulfide liquid phase enriched in $\mathrm{Cu}, \mathrm{Pt}, \mathrm{Pd}$ and $\mathrm{Au}$ which settled into zones of brecciated country rock to form stockworks of massive sulfide veins containing $\mathrm{Pt}, \mathrm{Pd}$ and $\mathrm{Au}$ at concentrations in the 1$10 \mathrm{ppm}$ range (Naldrett and Kullerud 1967; Cowan 1968; Li 1993; Li and Naldrett 1994; Morrison et al. 1994; Ebel and Naldrett 1997). Geochemical modeling of the ore compositions indicate a base and precious metal zonation within the footwall-style deposits that is generally consistent with sulfide fractionation (Li 1993). Physical connections between the footwall-style ores and contact-style ores are observed, for example, at the McCreedy West mine on the northern margin of the SIC; this observation supports the magmatic model for footwall-style deposit formation (Farrow and Lightfoot 2002). However, in several footwall-style deposits, $\mathrm{Au}$ (and to a lesser extent, $\mathrm{Pt}$ and $\mathrm{Pd}$ ) distribution within the footwall-style ore zones is difficult to predict rigorously using traditional models of sulfide liquid fractionation (Naldrett and Pessaran 1992; Li and Naldrett 1994; Li 1993). For example, at the Fraser Mine, $\mathrm{Cu}: \mathrm{Au}$ ratios in footwall-style sulfide samples can vary by three orders of magnitude within single veins; this variation cannot be explained by magmatic fractionation processes within the vein during emplacement $(\mathrm{Li}$ 1993). Unlike Pt and $\mathrm{Pd}, \mathrm{Au}$ concentrations tend to increase with decreasing $\mathrm{S}$ content in the ores and are highest in disseminated sulfide haloes surrounding massive sulfide veins, and notably, quartz-sulfide-epidote alteration veins adjacent to the ores $(\mathrm{Li} 1993$; Farrow 1994).

In the hydrothermal hypothesis, Farrow (1994) originally proposed that high salinity hydrothermal fluids (driven by the heat of the cooling SIC) leached $\mathrm{Cu}, \mathrm{Pt}, \mathrm{Pd}$ and $\mathrm{Au}$ from contact-style mineralization and re-deposited the metals in the footwall. This model has considerable merit and is supported by fluid inclusion, structural and mineralogical evidence that implicates a complex hydrothermal history in the footwall involving primary and secondary Cl-rich brines. Major points of evidence supporting a hydrothermal model for the ores include: (1) the occurrence of high salinity fluid inclusions in both sulfides and silicate alteration minerals that contain ore metals (e.g., $\mathrm{Ag}, \mathrm{Cu}$; Farrow 1994); (2) the occurrence of metal halide minerals within the PGE-Au-rich sulfide vein assemblages (e.g., an unnamed $\mathrm{Pd}-\mathrm{Bi}-\mathrm{Cl}$ phase; $\mathrm{Li}$ 1993); (3) the occurrence of primarily low temperature $\mathrm{Pt}$ and $\mathrm{Pd}$ minerals (e.g., $\quad<600^{\circ} \mathrm{C}$; tellurides, bisthmuthide, stannides) hosted in chlorine-rich alteration assemblages along the edges of massive sulfide veins rather than in the massive sulfide veins themselves $(\mathrm{Li}$ 1993; Farrow 1994); and (4) the presence of oxidized and intensely altered (?Cu-Au-Pt-Pd-leached) zones of high Ni-content ores along the SIC-footwall contact ("epidote-zone" mineralization; Farrow 1994). The most comprehensive fluid inclusion study in support of the hydrothermal model was conducted by Molnar et al. (2001). A summary of the major contributions to the hydrothermal model can be found in Table 1; these will be referred to in light of our new observations below.

Although at present most researchers have generally accepted that the emplacement of fractionated sulfide liquids initially concentrate the PGE and $\mathrm{Au}$ in the footwall setting, a late hydrothermal component was clearly responsible for significant compositional modification of magmatic sulfides, redistribution of the base 


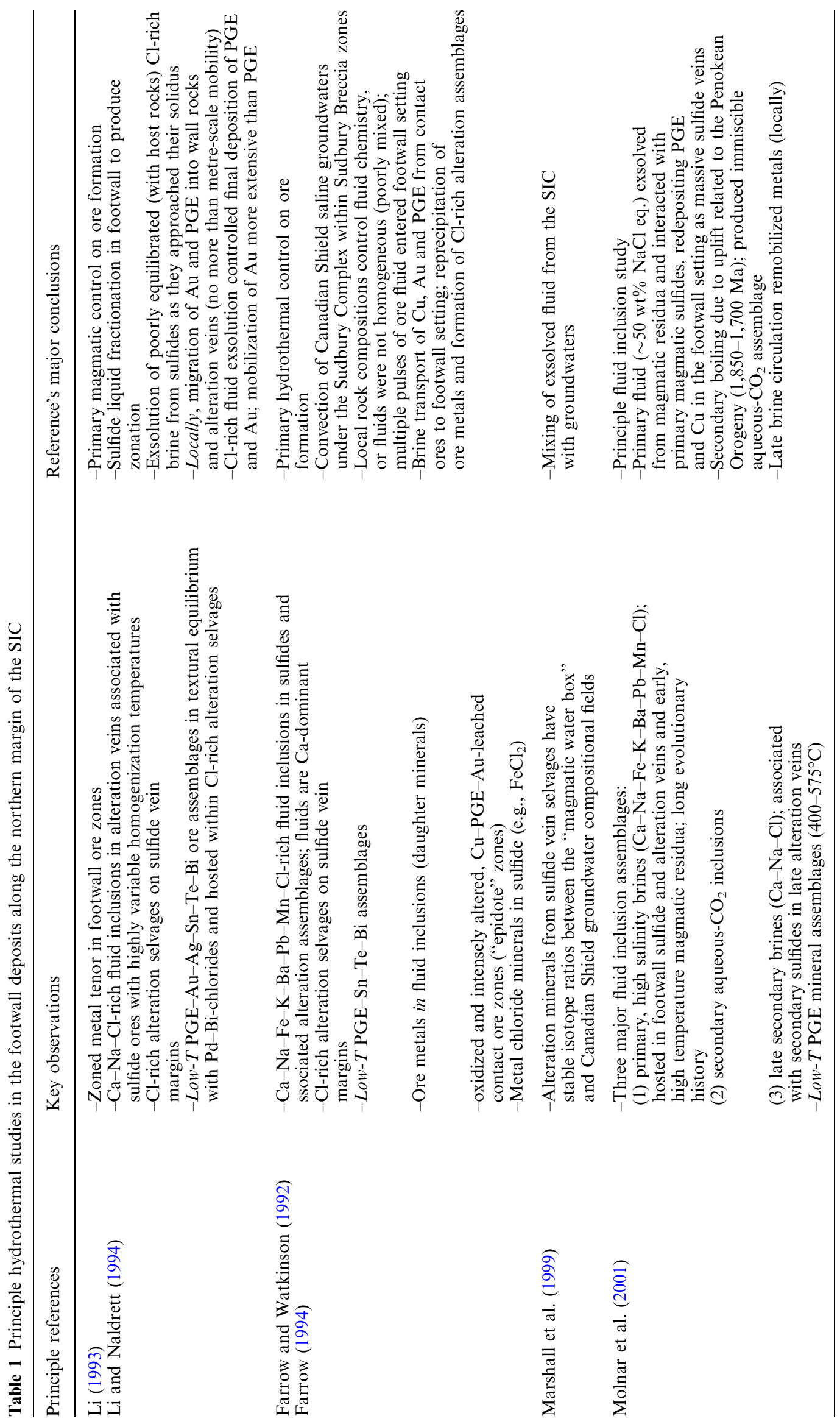


and precious metals and the formation of a halogenenriched alteration halo around the ores.

\section{Materials and methods}

Fluid inclusion analysis was conducted on samples obtained from underground exposures of typical footwallstyle $\mathrm{Cu}-\mathrm{PGE}$ ore in Zone 38 of the Fraser Mine (Fig. 1; Falconbridge Ltd). The samples consisted of fragments of quartz-sulfide-epidote "alteration" veins which splay or bifurcate from massive chalcopyrite-cubanite veins (Fig. 1c, d). Although volumetrically insignificant when compared to the massive sulfide veins, the alteration veins sampled for this study are widespread in footwallstyle deposits and have been documented at all footwallstyle deposits along the northern margin of the SIC ( $\mathrm{Li}$ 1993; Farrow 1994; Molnar et al. 2001). The alteration veins are rich in PGE and $\mathrm{Au}$; they may contain up to $15 \mathrm{ppm} \mathrm{Au}, 7 \mathrm{ppm}$ Pd and $5 \mathrm{ppm}$ Pt on a bulk rock basis (Hanley 2002). The mineralogical and fluid inclusion characteristics of the quartz-bearing veins sampled are described below.

All fluid inclusion analysis was performed on quartzhosted inclusions. Microthermometry was carried out on microscope-mounted Linkam THMS600 heating-cooling and Leitz 1350 high temperature stages at the Department of Geology, University of Toronto. Uncertainties associated with microthermometric measurements are $\pm 5^{\circ} \mathrm{C}$ for $T \mathrm{~s}>560^{\circ} \mathrm{C}, \pm 0.1^{\circ} \mathrm{C}$ for $T$ s between -95 and $0^{\circ} \mathrm{C}$ and $\pm 1{ }^{\circ} \mathrm{C}$ for $T$ s between 0 and $560^{\circ} \mathrm{C}$.

Hydrocarbon species in fluid inclusions were identified using gas chromatography (GC) at the University of Toronto. A bulk analysis of volatile compounds $\left(\mathrm{N}_{2}\right.$, $\mathrm{H}_{2} \mathrm{O}, \mathrm{CO}_{2}, \mathrm{C}_{1}-\mathrm{C}_{5}$ hydrocarbons, $\mathrm{COS}, \mathrm{SO}_{2}$ ) in the inclusions was obtained by heated $\left(110^{\circ} \mathrm{C}\right)$ crushing of quartz followed by on-line GC at the Department of Geology, University of Toronto using an HP 5890 gas chromatograph equipped with PID and TCD detectors; details of the analytical procedure and instrumentation can be found in Bray and Spooner (1992).

Element concentrations in fluid and halide-melt inclusions were determined by laser ablation ICPMS (ETH Zurich, Switzerland); the analytical approach for fluid inclusions is described in Heinrich et al. (2003). Ablation was done with a GEOLAS $193 \mathrm{~nm}$ ArF Excimer laser operated at 85-90 mJ output energy, and employing a pulsed beam with an energy-homogenized beam profile (Gunther et al. 1997). Ablated aerosols were transported into an ELAN 6100 quadrupole ICPMS operated in dual detector mode at conditions similar to those reported in Pettke et al. (2004). The following element masses were analyzed and detected in the inclusions: ${ }^{7} \mathrm{Li},{ }^{11} \mathrm{~B},{ }^{23} \mathrm{Na},{ }^{25} \mathrm{Mg},{ }^{27} \mathrm{Al},{ }^{39} \mathrm{~K},{ }^{42} \mathrm{Ca}$, ${ }^{55} \mathrm{Mn},{ }^{57} \mathrm{Fe},{ }^{65} \mathrm{Cu},{ }^{66} \mathrm{Zn},{ }^{85} \mathrm{Rb},{ }^{88} \mathrm{Sr},{ }^{107} \mathrm{Ag},{ }^{118} \mathrm{Sn},{ }^{133} \mathrm{Cs}$, ${ }^{137} \mathrm{Ba},{ }^{195} \mathrm{Pt},{ }^{197} \mathrm{Au},{ }^{208} \mathrm{~Pb}$ and ${ }^{209} \mathrm{Bi}$. Spectrometer dwell time was set to $10 \mathrm{~ms}$ for all elements but was increased for certain elements during short menu analytical sessions in order to improve detection limits $\left[{ }^{65} \mathrm{Cu}\right.$ $(20 \mathrm{~ms}),{ }^{107} \mathrm{Ag}(20 \mathrm{~ms}),{ }^{209} \mathrm{Bi}(30 \mathrm{~ms}),{ }^{197} \mathrm{Au}(50 \mathrm{~ms})$, and $\left.{ }^{195} \mathrm{Pt}(50 \mathrm{~ms})\right]$. Data reduction followed procedures outlined by Longerich et al. (1996) and Heinrich et al. (2003). $\mathrm{NaCl}$ wt $\%$ eq. concentrations (from microthermometry) were converted to absolute wt $\%$ concentrations of $\mathrm{Na}$ using a correction for the presence of other major Cl-complexing cations (e.g., $\mathrm{Ca}^{2+}, \mathrm{Fe}^{2+}, \mathrm{Ba}^{2+}$ ) in the inclusions (Heinrich et al. 2003). The resulting $\mathrm{Na}$ concentrations were used as the internal standard values to calculate element concentrations in the fluid inclusions.

\section{Results}

\section{Petrography}

Hydrocarbon inclusions containing mainly $\mathrm{CH}_{4}$ (confirmed by microthermometry, and bulk GC analysis; see below) were observed in hydrothermal quartz in crack-seal type alteration veins splaying from massive sulfide veins within brecciated Levack Gneiss (Sudbury Breccia; Fig. 2a). The alteration veins extend outward to a maximum of $\sim 5 \mathrm{~m}$ from the parent massive sulfide veins and are most abundant near the terminations of massive sulfide veins (Fig. 1d). The quartz is intergrown with minor (less than $5 \mathrm{vol} \%$ ) large (up to $\mathrm{cm}$ length) acicular epidote crystals. Occasionally, minor calcite is also observed. Texturally, these minerals appear to have crystallized at the same time. Silicate minerals were then replaced (fracture-controlled) by massive chalcopyrite with minor $(<5 \mathrm{vol} \%)$ millerite and bornite (Fig. 2b, c). Electrum (up 60 elemental wt $\%$ Ag; Farrow 1994) occurs primarily $(90 \%$ of occurrences) as euhedral to subhedral crystals along silicate-silicate grain margins or as fracture-infillings in the silicate phases (Fig. 2d). Sulfide content in the alteration veins decreases with increasing distance from the massive sulfide parent vein.

Hydrocarbon fluid inclusions occur with high salinity aqueous inclusions (brine) as a primary assemblage in the quartz (designated type $\mathrm{P}_{\mathrm{CH} 4}$ and $\mathrm{P}_{\text {brine }}$ inclusions; Fig. 3a) [Note that brine inclusions of primary origin (without coexisting hydrocarbon inclusions) were described in detail by Li (1993), Farrow (1994) and Molnar et al. (2001)]. Commonly, inclusions in the assemblage contain both a hydrocarbon phase and brine within the same inclusion and show highly variable phase ratios (Fig. 3b), indicating heterogeneous entrapment of coexisting fluid phases. $\mathrm{P}_{\mathrm{CH} 4}$ and $\mathrm{P}_{\text {brine }}$ inclusions occur in random, three-dimensional arrays rather than planar orientations and commonly show elongation and tapering in the inferred direction of quartz growth (Fig. 3c); these observations are consistent with established criteria for a primary origin (Goldstein 2003). In addition to halite, the $\mathrm{P}_{\text {brine }}$ inclusions contain at least one and as many as five additional daughter crystals. This characteristic is consistent with the classification of 

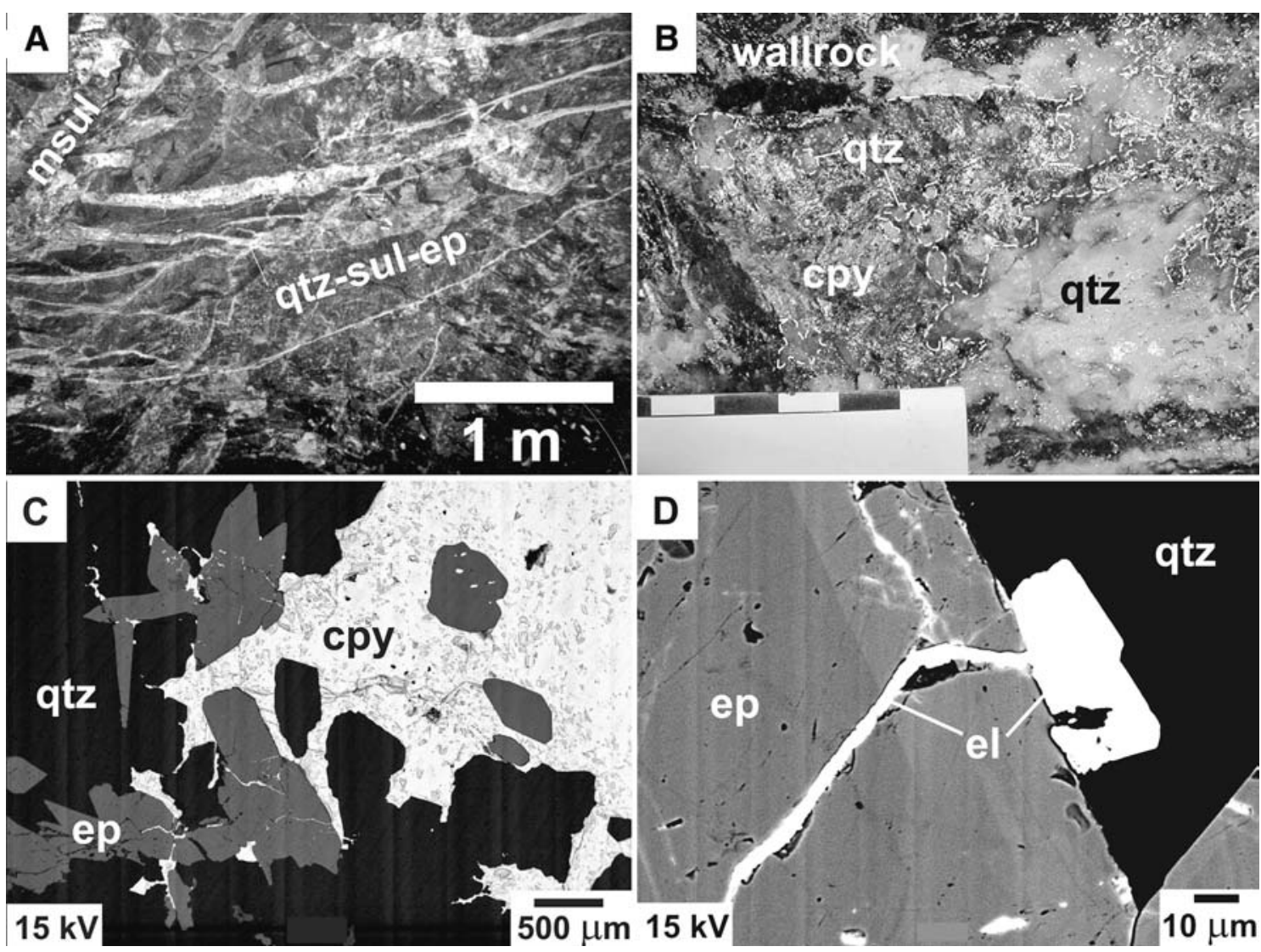

Fig. 2 Textural and petrographic characteristics of Au-rich quartzepidote-sulfide-carbonate alteration veins in the Fraser $\mathrm{Cu} Z$ Zone. a An underground exposure (drift wall) of a network of sub-parallel crack-seal alteration veins (qtz-sul-ep) in Sudbury Breccia, connected to a massive sulfide vein (msul). b Magnified view of an alteration vein showing replacement of quartz by chalcopyrite. $\mathbf{c}$ Back-scattered electron image (SEM) of fracture-controlled, pervasive replacement of earlier quartz $(q t z)$-epidote $(e p)$ intergrowth by chalcopyrite. d Back-scattered electron image of electrum $(e l)$ along a grain boundary between a zoned epidote grain (ep) and quartz (qtz), and as a fracture filling in the epidote

primary brine inclusions in the study area by other researchers and differentiates the $\mathrm{P}_{\text {brine }}$ inclusions from secondary aqueous inclusions which contain only halite (e.g., Molnar et al. 2001).

Hydrocarbon inclusions also occur along curved to linear, healed fracture planes coexisting with inclusions of solid halite (designated $\mathrm{S}_{\mathrm{CH} 4}$ and $\mathrm{S}_{\text {halite }}$ inclusions; Fig. $3 \mathrm{~d}-\mathrm{i}$ ). The inclusion trails are not truncated by growth zones in the quartz, but cut across grain boundaries of adjoining quartz grains and are probably secondary in origin. The inclusions containing the halite are not cubic in shape; rather, they are elongated, tubelike or highly irregular ("amoeboid") in appearance (Fig. 3d). Commonly, inclusions containing both a hydrocarbon phase and halite were observed in the trails (Fig. 3f), indicating the coexistence of both phases at the time of entrapment. Small amounts of aqueous fluid occur with the solid halite (Fig. 3g, h), visible as a thin film of ice crystals only during freezing measurements. However, no aqueous-dominant (brine) inclusions were

observed in the $\mathrm{S}_{\mathrm{CH} 4}$ and $\mathrm{S}_{\text {halite }}$ trails, nor do any inclusions in the trails contain a significant amount (i.e., more than $\sim 5 \%$ by vol.) aqueous fluid. Except where they contain a visible amount of brine or halite (by

Fig. 3 Photomicrographs (plane-polarized transmitted light) of hydrocarbon-bearing inclusion assemblages in quartz. Abbreviations: $v$ vapor; $b$ brine; $h$ halite daughter (from brine); $s$ additional daughter phase (from brine). a Primary inclusions showing coexisting brine and hydrocarbon phases $\left(\mathrm{P}_{\mathrm{CH} 4}, \mathrm{P}_{\text {brine }}\right)$. b A primary inclusion which has trapped both hydrocarbon and brine phases (by heterogeneous entrapment). c Primary inclusions ( $\mathrm{P}_{\text {brine }}$ $\mathrm{P}_{\mathrm{CH} 4}$ ) showing alignment, tapering and elongation in the inferred direction of quartz growth as a characteristic of primary origin. Inset image was slightly to the left of the main field of view. Quartz growth direction indicated with dashed arrows. Small arrows indicate tapered or "pinched" ends of the inclusions. In the main field of view, a trail of secondary brine inclusions $\left(\mathrm{S}_{\text {brine }}\right)$ is also visible. d Trail of large, halite inclusions $\left(S_{\text {halite }}\right)$ near grain boundary between a quartz (qtz) and chalcopyrite (cpy) grain. Note that the central inclusion is highly irregular in shape (i.e., not cubic) and contains both halite and hydrocarbons $\left(\mathrm{S}_{\text {halite }}+\mathrm{S}_{\mathrm{CH} 4}\right)$. e Secondary inclusions containing solid halite (melt) and hydrocarbon phases $\left(\mathrm{S}_{\mathrm{CH} 4}, \mathrm{~S}_{\text {halite }}\right)$. The halite-bearing inclusion shows a small, flattened vapor bubble. f A secondary inclusion which has trapped both the hydrocarbon phase and halite. $\mathbf{g} \mathrm{A} \mathrm{S}_{\text {halite }}$ inclusion imaged at $20^{\circ} \mathrm{C}$; note the lack of contrast between the halite and host quartz due to their similar refractive indices. $\mathbf{h}$ The same $\mathrm{S}_{\text {halite }}$ inclusion shown in (g) but photographed at $-193^{\circ} \mathrm{C}$; freezing of a thin film of aqueous fluid in the wall interstices of the halite inclusion has occurred and ice crystals are visible on the surface of the halite. i A trail of $\mathrm{S}_{\mathrm{CH} 4}$ and $\mathrm{S}_{\text {halite }}$ inclusions; note the hydrocarbon-rich and halite-rich segments of the trail. Image obtained at $20^{\circ} \mathrm{C}$ 
heterogeneous entrapment; $\sim 10 \%$ of inclusions examined), $\mathrm{S}_{\mathrm{CH} 4}$ and $\mathrm{P}_{\mathrm{CH} 4}$ inclusions show a single phase (either hydrocarbon L, V, or supercritical fluid, depending on density) at room temperature. Additionally, a very thin film of aqueous fluid wetting the wall of the $\mathrm{S}_{\mathrm{CH} 4}$ and $\mathrm{P}_{\mathrm{CH} 4}$ inclusions was identified during freezing measurements.

Secondary brine inclusions [designated $\mathrm{S}_{\text {brine }}$ inclusions; described by Molnar et al. (2001)] also occur in the quartz. They occur in trails which crosscut or offset, and therefore, post-date planes of $\mathrm{S}_{\mathrm{CH} 4}$ and $\mathrm{S}_{\text {halite }}$ inclusions. Secondary $\mathrm{CO}_{2}$-dominant inclusions reported previously by Molnar et al. (2001) were not observed in any of the samples examined.

The overall observed paragenetic inclusion history is (in order of decreasing age of entrapment): $\mathrm{P}_{\mathrm{CH} 4}+P_{\text {brine }}$ $\rightarrow S_{\mathrm{CH} 4}+S_{\text {halite }} \rightarrow S_{\text {brine }}$. A representative schematic map (based on a photomicrograph) showing the textural relationships among different inclusion assemblages in the quartz samples is shown in Fig. 4.
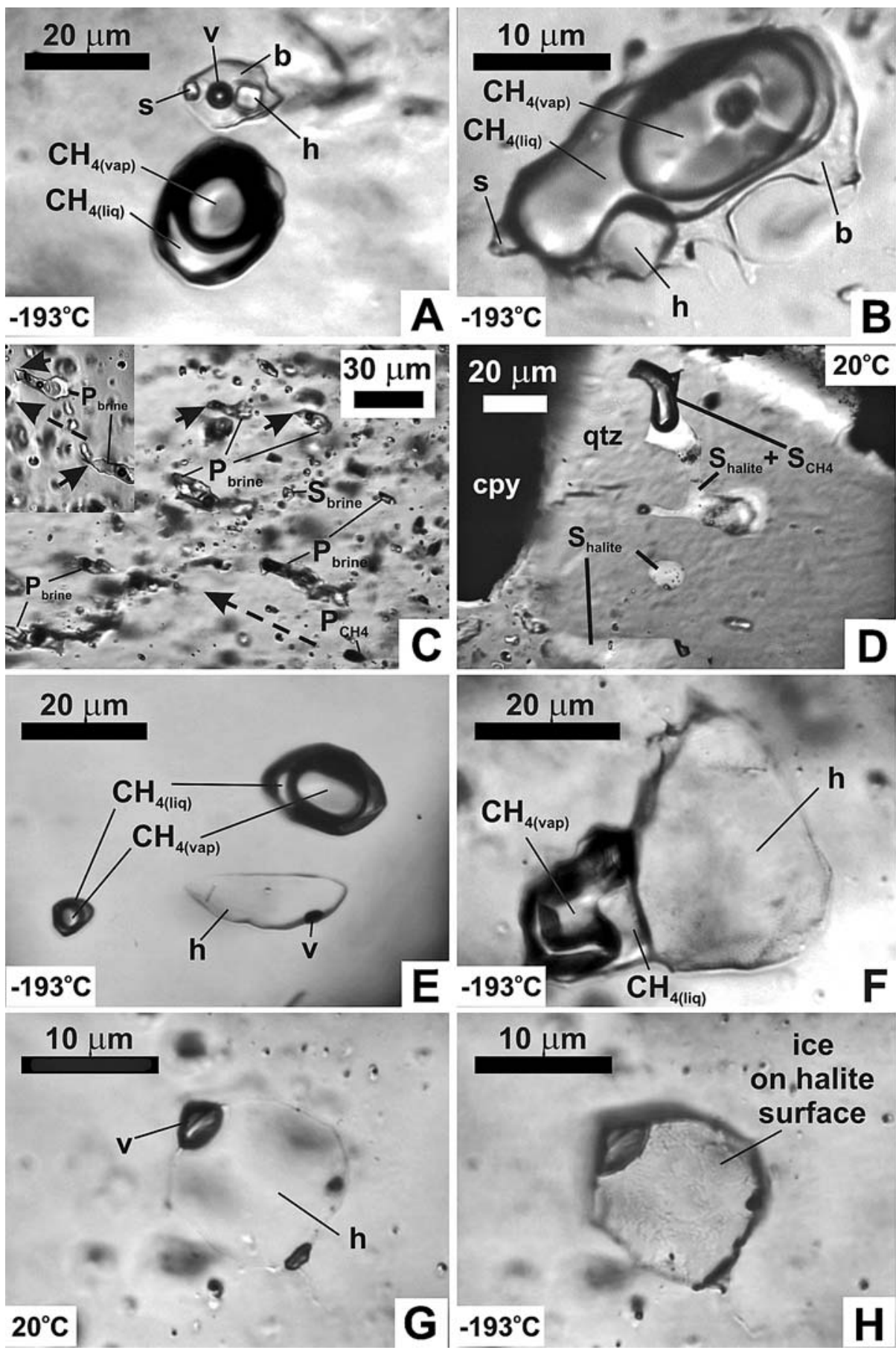
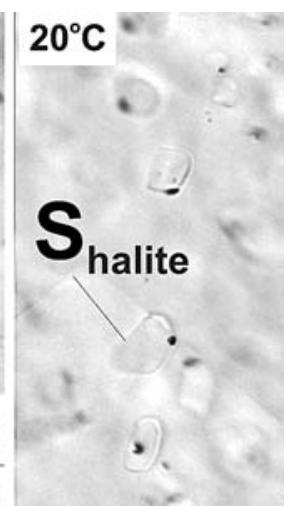


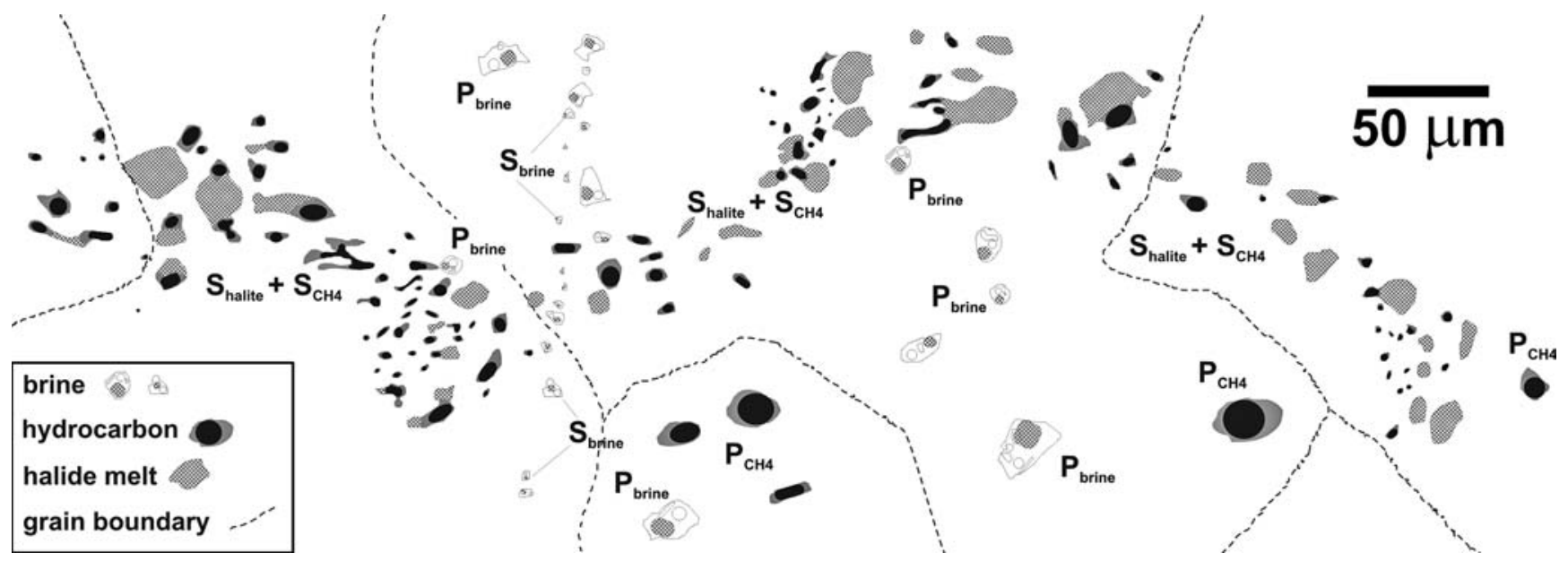

Fig. 4 Fluid inclusion map (based on a photomicrograph) showing the textural relationships between fluid inclusion assemblages observed in the alteration vein quartz. The earliest fluid assemblage consists of primary inclusions containing brine $\left(\mathrm{P}_{\text {brine }}\right)$ or hydrocarbon $\left(\mathrm{P}_{\mathrm{CH} 4}\right)$ phases. $\mathrm{P}_{\text {brine }}$ inclusions contain brine, vapor, halite and at least one additional daughter mineral phase. Primary inclusions that trapped both brine and hydrocarbon phases (heterogeneous entrapment) were not observed in this area of the section. An early secondary assemblage of halite $\left(\mathrm{S}_{\text {halite }}\right), \mathrm{CH}_{4}$ $\left(\mathrm{S}_{\mathrm{CH} 4}\right)$, and heterogeneously trapped halite $+\mathrm{CH}_{4}$ ( $\mathrm{S}_{\text {hali- }}$ te $+\mathrm{SCH} 4$ ) inclusions occurs as a wide trail across the mapped area, crosscutting several grain boundaries. A narrow trail of late secondary brine inclusions $\left(\mathrm{S}_{\text {brine }}\right)$ cuts across the early secondary halite $+\mathrm{CH}_{4}$ inclusion trail at the center left of the map and were the last inclusions to form

\section{Microthermometry}

A detailed microthermometric study of $\mathrm{P}_{\text {brine }}$ inclusions (occurring without coexisting $\mathrm{P}_{\mathrm{CH} 4}$ inclusions) in quartzsulfide-epidote alteration veins at the Fraser Mine was conducted by Molnar et al. (2001). Some $\mathrm{P}_{\text {brine }}$ inclusions were heated in order to confirm that their high temperature behavior is comparable to that reported by Molnar et al. (2001). Molnar et al. (2001) reported that total homogenization $\left(T_{\mathrm{h}}\right)$ of $\mathrm{P}_{\text {brine }}$ inclusions in quartzepidote sulfide veins occurred by halite dissolution between $\sim 150$ and $290^{\circ} \mathrm{C}$; vapor bubble disappearance

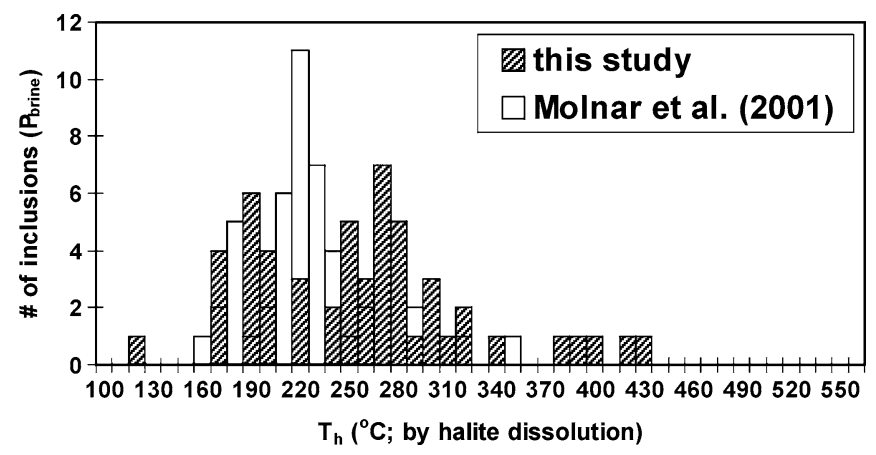

Fig. 5 Histogram showing the temperature range of final homogenization by halite dissolution $\left(T_{\mathrm{h}}\right)$ of $\mathrm{P}_{\text {brine }}$ inclusions occurring with hydrocarbon inclusions (this study) and without hydrocarbon inclusions (Molnar et al. 2001). The range in final homogenization temperatures of the data sets overlap with one another

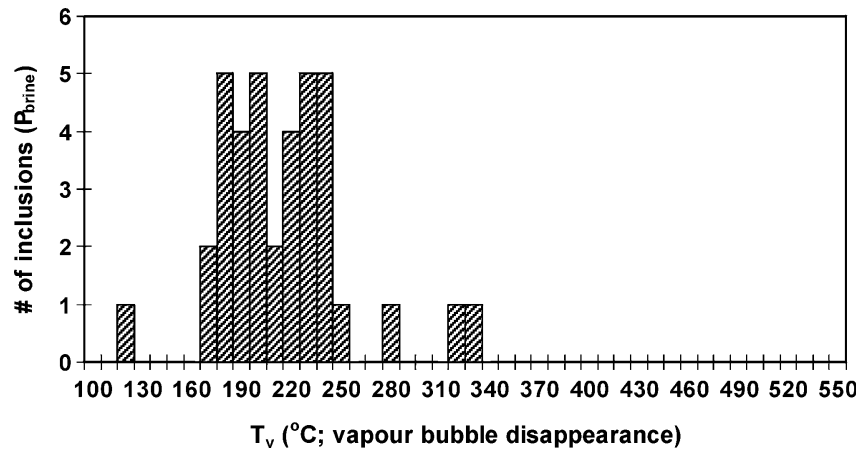

Fig. 6 Histogram showing the temperature range of vapor bubble disappearance $\left(T_{\mathrm{v}}\right)$ in $\mathrm{P}_{\text {brine }}$ inclusions occurring with hydrocarbon inclusions (this study)

occurred slightly below the $T_{\mathrm{h}}$, and ranged from 96 to $235^{\circ} \mathrm{C}$. For comparison, $\mathrm{P}_{\text {brine }}$ inclusions coexisting with $\mathrm{P}_{\mathrm{CH} 4}$ inclusions in this study always homogenized by halite dissolution between $\sim 145$ and $315^{\circ} \mathrm{C}$ (mean $=230 \pm 43^{\circ} \mathrm{C} \quad[n=53,1 \sigma]$ ), corresponding to salinities between 29.5 and $39.3 \mathrm{wt} \%$ eq. $\mathrm{NaCl}$. $($ mean $=33.5 \pm 2.6 \mathrm{wt} \%$ eq. $\mathrm{NaCl}[n=53,1 \sigma])($ Fig. 5$)$. Vapor bubble disappearance occurred between 117 and $325^{\circ} \mathrm{C}\left(\right.$ mean $\left.=211 \pm 39^{\circ} \mathrm{C}[n=53,1 \sigma]\right)($ Fig. 6).

When cooled to $-93^{\circ} \mathrm{C}, \mathrm{P}_{\mathrm{CH} 4}$ and $\mathrm{S}_{\mathrm{CH} 4}$ inclusions show an inner bubble of low refractive index vapor ( $\sim 50-60 \mathrm{vol} \%$ of the inclusion) surrounded by a more refractive liquid $(\sim 40-50 \mathrm{vol} \%)$. The inability to freeze the $\mathrm{P}_{\mathrm{CH} 4}$ and $\mathrm{S}_{\mathrm{CH} 4}$ inclusion contents using liquid $\mathrm{N}_{2}$ indicates that additional volatile components with $T_{\text {triple }}$ below that for pure $\mathrm{CH}_{4}\left(-82.5^{\circ} \mathrm{C}\right)$ are probably present (see below), although significant undercooling is often required to induce freezing. Upon heating, the hydrocarbon phase in $\mathrm{P}_{\mathrm{CH} 4}$ inclusions homogenizes by nearcritical behavior to either liquid or vapor, or by critical behavior at $T$ s between -87 and $-73^{\circ} \mathrm{C}$ (mean = $\left.1.4 \pm 2.1^{\circ} \mathrm{C}[n=40,1 \sigma]\right)$, suggesting that $\mathrm{CH}_{4}$ is the principal species $\left(T_{\text {critical }}=-2.6^{\circ} \mathrm{C}\right) \quad$ (Fig. 7). The hydrocarbon phase in $\mathrm{S}_{\mathrm{CH} 4}$ inclusions always homogenized to vapor at $T$ s between -71 and $-49^{\circ} \mathrm{C}$ $\left(\right.$ mean $\left.=-4.9 \pm 7.0^{\circ} \mathrm{C}[n=28,1 \sigma]\right)$, indicating that sig- 


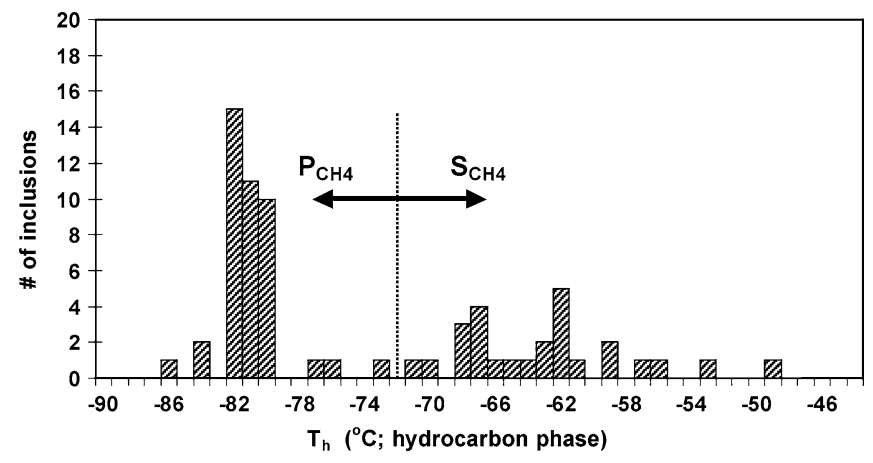

Fig. 7 Histogram showing the range in $T_{\mathrm{h}}$ of the hydrocarbon phase in $\mathrm{P}_{\mathrm{CH} 4}$ and $\mathrm{S}_{\mathrm{CH} 4}$ inclusions. $\mathrm{P}_{\mathrm{CH} 4}$ inclusions homogenize close to the critical $T$ for pure $\mathrm{CH}_{4}\left(-2.6^{\circ} \mathrm{C}\right)$, whereas $\mathrm{S}_{\mathrm{CH} 4}$ inclusions homogenize at higher temperatures than the critical $T$ and therefore contain additional volatiles

nificant quantities of volatile compounds in addition to $\mathrm{CH}_{4}$ must be present (Fig. 7). With continued heating, the formation of a thin layer of dendritic ice crystals between -9 and $-41^{\circ} \mathrm{C}$ was visible along the exposed (upper) wall of the $\mathrm{S}_{\mathrm{CH} 4}$ and $\mathrm{P}_{\mathrm{CH} 4}$ inclusions, indicating that a small amount of brine is present in the inclusions. Final melting of the ice occurred between -31 and $-21^{\circ} \mathrm{C}$. No further phase changes were observed above $-21^{\circ} \mathrm{C}$; if final homogenization of the trace amount of aqueous brine and hydrocarbon phase occurred, it could not be observed. $\mathrm{P}_{\mathrm{CH} 4}$ or $\mathrm{S}_{\mathrm{CH} 4}$ inclusions that contained significant amounts of brine always decrepitated upon heating at $T>400^{\circ} \mathrm{C}$ and did not show any evidence that

Fig. 8 Photomicrographs (plane-polarized, transmitted light) of high temperature phase changes during heating of two $\mathrm{S}_{\text {halite }}$ inclusions. At $600^{\circ} \mathrm{C}$, the inclusion walls are poorly visible. Melting begins at $772^{\circ} \mathrm{C}$ and is characterized by a sudden change in the relief of the inclusions due to the formation of a thin layer of melt around the solid halite. At $774^{\circ} \mathrm{C}$, the melt:solid ratio begins to increase rapidly in the inclusion on the left side of the image. At $780^{\circ} \mathrm{C}$, the melt:solid ratio of the inclusion on the left exceeds $50 \mathrm{vol} \%$ and the first melt is visible in the inclusion on the right. The inclusion on the left side of the image has melted completely by $785^{\circ} \mathrm{C}$; less than $50 \mathrm{vol} \%$ of the halite remains in the inclusion on the right. At $787^{\circ} \mathrm{C}$, both inclusions show a single phase, high relief halide melt homogenization was about to occur before decrepitation (i.e., no changes in phase ratios), consistent with heterogeneous entrapment.

Heating of the $S_{\text {halite }}$ inclusions to very high $T$ $\left(>700^{\circ} \mathrm{C}\right)$ resulted in the melting of the halite (Fig. 8). Prior to melting, the disappearance of a tiny vapor bubble occurred, followed by the partial dissolution of the outer surface of the halite crystal into the small amount of aqueous brine surrounding the halite resulting in the appearance of a distinct boundary between the halite and wall of the inclusion. This occurred at $\sim 600^{\circ} \mathrm{C}$ for most inclusions (Fig. 8). The melting of halite $\left(T_{\mathrm{m}}\right)$ occurred between 710 and $805^{\circ} \mathrm{C}$; melting occurred rapidly over a $\sim 10^{\circ} \mathrm{C}$ interval leading up to the final disappearance of the halite; large groups of $\mathrm{S}_{\text {halite }}$ inclusions melted simultaneously between 770 and $805^{\circ} \mathrm{C}$ (Figs. 8, 9). Melting temperatures below the solidus $T$ of pure halite $\left(\sim 815^{\circ} \mathrm{C}\right.$ at $\left.0.5 \mathrm{kbar}\right)$ indicate that other volatiles or cations are present in the inclusions. The presence of additional cations in the $S_{\text {halite }}$ inclusions was confirmed by X-ray mapping and LA-ICP-MS analysis (see below).

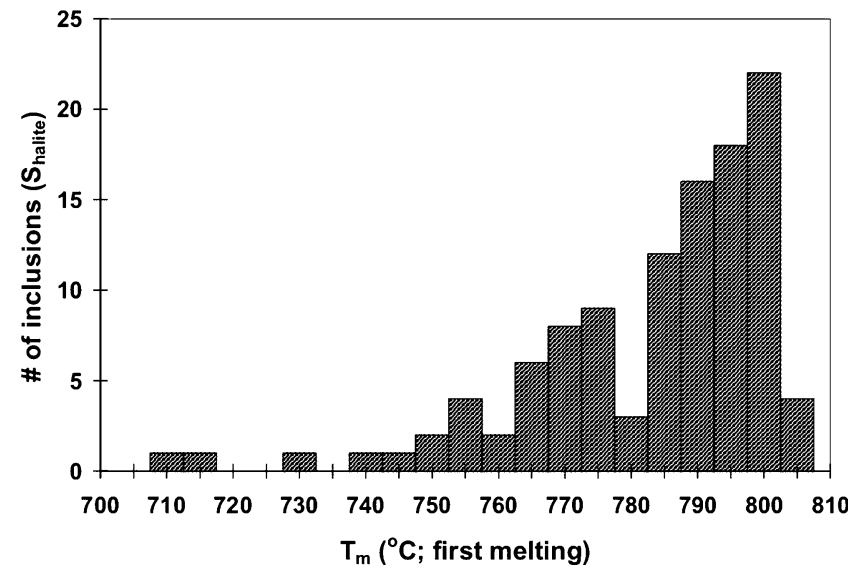

Fig. 9 Histogram showing the range in melting temperatures in $\mathrm{S}_{\text {halite }}$ inclusions occurring with $\mathrm{CH}_{4}$. Melting $T$ 's below that for pure halite $\left(\sim 815^{\circ} \mathrm{C}\right.$ at $\left.0.5 \mathrm{kbar}\right)$ are due to the presence of aqueous fluid containing other components (e.g., $\mathrm{H}_{2} \mathrm{O}$ ) lowering the solidus.
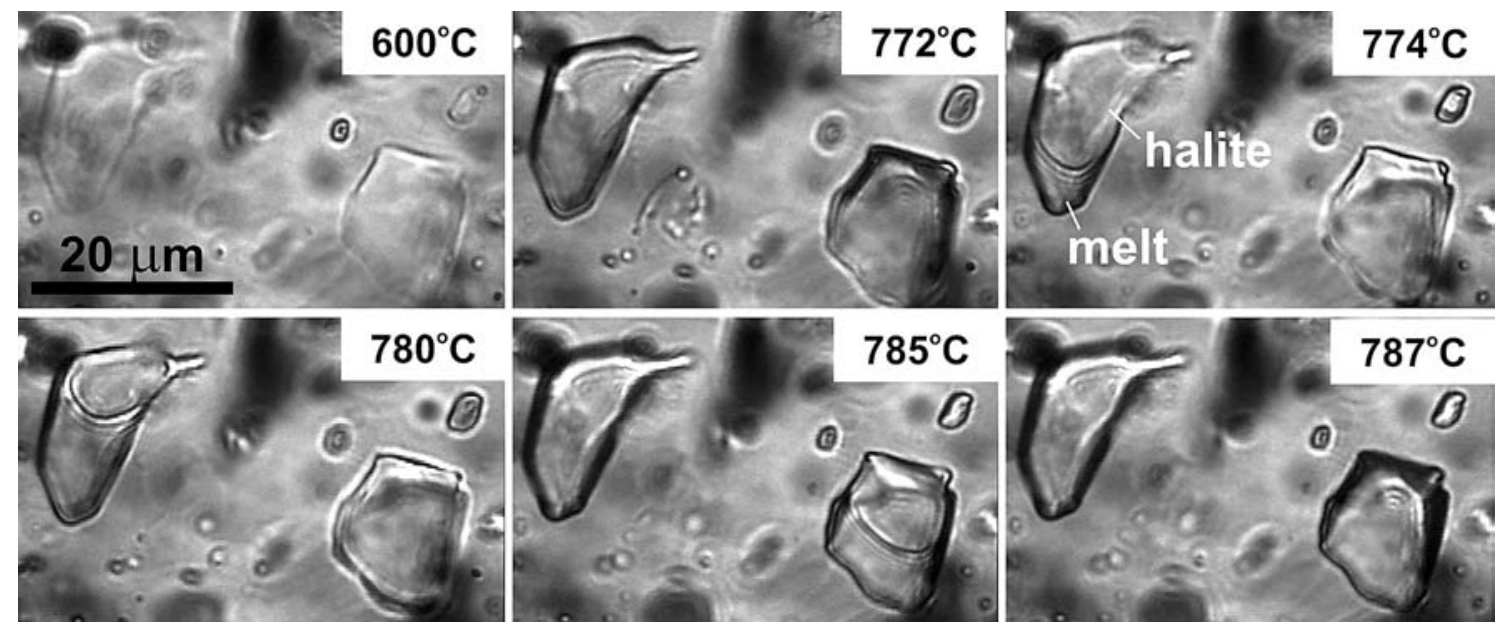
(Note that it is possible that during the earlier study of Molnar et al. (2001), trails of hydrocarbon inclusions were misidentified as $\mathrm{CO}_{2}$ inclusions. Additionally, we found that halite inclusions are extremely difficult to identify without freezing or heating because the refractive indices of halite and quartz are identical).

\section{Bulk analysis of volatiles by GC}

In order to confirm the presence of $\mathrm{CH}_{4}$ as the primary hydrocarbon species (as suggested by low- $T$ microthermometric behavior), quartz containing abundant $\mathrm{P}_{\text {brine, }}, \mathrm{P}_{\mathrm{CH} 4}, \mathrm{~S}_{\text {halite }}$, and $\mathrm{S}_{\mathrm{CH} 4}$ inclusions and relatively few $S_{\text {brine }}$ inclusions was crushed and the released volatiles were analyzed by GC. It is important to recognize that due to the presence of two major inclusion assemblages, the results obtained represent a mixed signal with aqueous and non-aqueous volatile species from four different fluid inclusion types. Therefore, the results listed below cannot be taken as true concentrations of volatiles in any single inclusion type or assemblage, but nevertheless are valuable for the identification of compounds present.
The quartz sample yielded the following analysis (each value in mole \%): $97.2 \% \mathrm{H}_{2} \mathrm{O} ; 1.79 \% \mathrm{CH}_{4} ; 0.79 \%$ $\mathrm{C}_{2} \mathrm{H}_{6}-\mathrm{C}_{2} \mathrm{H}_{2} ; 0.11 \% \mathrm{~N}_{2} ; 0.07 \% \mathrm{C}_{3} \mathrm{H}_{8}$. Other analyzed species were present at relative concentrations of less than 0.01 mole $\%$, or were undetected. Notably, $\mathrm{CO}_{2}$ accounted for only 0.003 mole $\%$ of the total volatile content. This analysis does not represent the composition of only the hydrocarbon phases due to the diluting effect of $\mathrm{H}_{2} \mathrm{O}$ from the brine inclusions on the bulk analysis. Therefore, recasting the analysis by excluding $\mathrm{H}_{2} \mathrm{O}$ and assuming that there is relatively little of the gas species dissolved in the brine inclusions (Poling et al. 2001) yields an approximate composition of the hydrocarbon fluid from mixed $\mathrm{P}_{\mathrm{CH} 4}$ and $\mathrm{S}_{\mathrm{CH} 4}$ inclusions of: $\sim 64 \%$ $\mathrm{CH}_{4}, 29 \% \mathrm{C}_{2} \mathrm{H}_{6}-\mathrm{C}_{2} \mathrm{H}_{2}, 4 \% \mathrm{~N}_{2}$, and $3 \% \mathrm{C}_{3} \mathrm{H}_{8}$.

The analysis is consistent with the unusual microthermometric behavior observed in the $\mathrm{P}_{\mathrm{CH} 4}$ and notably, the $\mathrm{S}_{\mathrm{CH} 4}$ inclusions. The $T_{\text {triple }}$ of $\mathrm{N}_{2}$ and $\mathrm{C}_{3} \mathrm{H}_{8}$ are -10 and $-88^{\circ} \mathrm{C}$, respectively; the presence of $\mathrm{N}_{2}$ and $\mathrm{C}_{3} \mathrm{H}_{8}$ will therefore lower the bulk freezing $T$ of the hydrocarbon fluid, possibly explaining our inability to freeze the hydrocarbon phase in $\mathrm{P}_{\mathrm{CH} 4}$ and $\mathrm{S}_{\mathrm{CH} 4}$ inclusions using liquid $\mathrm{N}_{2}$. Additionally, because of the relatively high $T_{\text {critical }}$ of $\mathrm{C}_{2} \mathrm{H}_{6}-\mathrm{C}_{2} \mathrm{H}_{2}\left(32.2^{\circ} \mathrm{C}\right.$ -

Table 2 Element concentrations (laser ablation ICP-MS) in $\mathrm{P}_{\text {brine }}$, $\mathrm{S}_{\text {halite }}$ and $\mathrm{P}_{\mathrm{CH} 4}$ inclusions

\begin{tabular}{|c|c|c|c|c|c|c|c|c|c|c|c|c|c|c|}
\hline \multirow[t]{2}{*}{ Element } & \multicolumn{4}{|c|}{${ }^{\mathrm{a}} \mathrm{P}_{\text {brine }}$ inclusions } & \multirow[t]{2}{*}{ Element } & \multicolumn{4}{|c|}{${ }^{\mathrm{c}} \mathrm{S}_{\text {halite }}$ inclusions } & \multirow[t]{2}{*}{ Element } & \multicolumn{4}{|c|}{${ }^{\mathrm{d}} \mathrm{P}_{\mathrm{CH} 4}$ inclusions } \\
\hline & ${ }^{\mathrm{b}}$ Mean $(n)$ & $1 \sigma$ & Max & Min & & ${ }^{\mathrm{b}}$ Mean $(n)$ & $1 \sigma$ & Max & Min & & ${ }^{\mathrm{b}}$ Mean $(n)$ & $1 \sigma$ & $\operatorname{Max}$ & Min \\
\hline $\mathrm{Ca}(\mathrm{wt} \%)$ & $11.08(50)$ & 1.93 & 16.42 & 7.27 & $\mathrm{Ca}(\mathrm{wt} \%)$ & 0.52 & 0.13 & 0.69 & 0.33 & $\mathrm{Ca}(\mathrm{ppm})$ & $3,780(14)$ & 1,796 & 6,683 & 375 \\
\hline $\mathrm{Na}$ & $6.16(50)$ & 1.19 & 8.42 & 3.70 & $\mathrm{Na}$ & $37.00(19)$ & 0.41 & 37.37 & 35.58 & $\mathrm{Na}$ & $1,935(18)$ & 1,196 & 4,574 & 399 \\
\hline K & $2.55(38)$ & 0.48 & 3.79 & 1.44 & $\mathrm{~K}(\mathrm{ppm})$ & $562(14)$ & 603 & 2,002 & 67 & $\mathrm{~K}$ & 994 (17) & 618 & 2,373 & 169 \\
\hline $\mathrm{Fe}$ & $1.17(38)$ & 0.49 & 2.31 & 0.27 & $\mathrm{Fe}$ & $9,627(4)$ & 15,592 & 36,627 & 198 & $\mathrm{Fe}$ & 383 (11) & 326 & 1,047 & 15 \\
\hline $\mathrm{Pb}$ & 1.03 & 0.24 & 1.82 & 0.32 & $\mathrm{~Pb}$ & $53(11)$ & 88 & 322 & 2.2 & $\mathrm{~Pb}$ & 150 (18) & 154 & 594 & 24 \\
\hline $\mathrm{Mn}$ & $0.64(38)$ & 0.16 & 1.27 & 0.24 & $\mathrm{Mn}$ & $66(4)$ & 71 & 188 & 22.4 & $\mathrm{Mn}$ & $75(17)$ & 70 & 262 & 4.0 \\
\hline $\mathrm{Zn}$ & $0.44(38)$ & 0.15 & 1.10 & 0.16 & $\mathrm{Zn}$ & $232(8)$ & 329 & 1,073 & 15 & $\mathrm{Zn}$ & $188(16)$ & 164 & 572 & 30 \\
\hline $\mathrm{Sr}$ & 0.44 (18) & 0.07 & 0.56 & 0.32 & $\mathrm{Sr}$ & $24(17)$ & 40 & 178 & 4.1 & $\mathrm{Sr}$ & NA & NA & NA & NA \\
\hline $\mathrm{Ba}$ & 0.43 & 0.08 & 0.69 & 0.31 & $\mathrm{Ba}$ & $20(15)$ & 19 & 73 & 4.0 & $\mathrm{Ba}$ & NA & NA & NA & NA \\
\hline $\mathrm{Cu}$ (ppm) & $156(37)$ & 232 & 993 & 4.9 & $\mathrm{Cu}$ & $4,486(14)$ & 3,381 & 11,125 & 17 & $\mathrm{Cu}$ & $1,286(17)$ & 2,395 & 9,737 & 18 \\
\hline $\mathrm{Al}$ & $136(18)$ & 116 & 460 & 12 & $\mathrm{Al}$ & $785(5)$ & 239 & 838 & 48 & $\mathrm{Al}$ & NA & NA & NA & NA \\
\hline $\mathrm{Mg}$ & $115(30)$ & 110 & 472 & 18 & $\mathrm{Mg}$ & $515(4)$ & 609 & 1,544 & 12 & $\mathrm{Mg}$ & NA & NA & NA & NA \\
\hline $\mathrm{Rb}$ & 109 (18) & 19 & 147 & 78 & $\mathrm{Rb}$ & $5.6(4)$ & 1.6 & 6.8 & 1.9 & $\mathrm{Rb}$ & NA & NA & NA & NA \\
\hline B & $84(17)$ & 24 & 153 & 49 & B & $117(6)$ & 110 & 354 & 33 & B & NA & NA & NA & NA \\
\hline $\mathrm{Sn}$ & 85 (14) & 91 & 296 & 8.1 & $\mathrm{Sn}$ & $24(5)$ & 16 & 54 & 11 & $\mathrm{Sn}$ & NA & NA & NA & NA \\
\hline $\mathrm{Li}$ & 74 (14) & 65 & 264 & 14 & $\mathrm{Li}$ & $955(15)$ & 978 & 2,850 & 4.0 & $\mathrm{Li}$ & NA & NA & NA & NA \\
\hline $\mathrm{Ag}$ & $15(44)$ & 7.6 & 41 & 3.6 & $\mathrm{Ag}$ & $138(18)$ & 253 & 775 & 1.0 & $\mathrm{Ag}$ & $20(15)$ & 37 & 157 & 0.5 \\
\hline Cs & $12(18)$ & 2.0 & 16 & 7.7 & Cs & 8.9 (5) & 16 & 40 & 0.4 & Cs & NA & NA & NA & NA \\
\hline $\mathrm{Pt}$ & $4.3(11)$ & 3.8 & 12 & 0.2 & $\mathrm{Pt}$ & $3.5(5)$ & 1.8 & 5.4 & 0.8 & $\mathrm{Pt}$ & ND & ND & ND & ND \\
\hline $\mathrm{Bi}$ & 4.1 (18) & 4.5 & 19 & 0.4 & $\mathrm{Bi}$ & $12(3)$ & 8.7 & 24 & 2.5 & $\mathrm{Bi}$ & $6.6(9)$ & 4.2 & 14 & 1.1 \\
\hline $\mathrm{Au}$ & $3.4(10)$ & 3.5 & 11 & 0.2 & $\mathrm{Au}$ & $6.1(5)$ & 7.5 & 21 & 0.4 & $\mathrm{Au}$ & $1.4(12)$ & 1.2 & 4.6 & 0.1 \\
\hline $\mathrm{Ca} / \mathrm{Na}$ & $1.9(50)$ & 0.7 & 4.2 & 1.0 & $\mathrm{Ca} / \mathrm{Na}$ & $0.03(7)$ & 0.03 & 0.1 & 0.01 & $\mathrm{Ca} / \mathrm{Na}$ & 3.9 (14) & 3.1 & 10 & 0.1 \\
\hline $\mathrm{Sr} / \mathrm{Rb}$ & $40(18)$ & 5.1 & 58 & 34 & $\mathrm{Sr} / \mathrm{Rb}$ & $19(7)$ & 19 & 53 & 1.0 & $\mathrm{Sr} / \mathrm{Rb}$ & $\mathrm{NC}$ & $\mathrm{NC}$ & $\mathrm{NC}$ & $\mathrm{NC}$ \\
\hline $\mathrm{Pb} / \mathrm{Zn}$ & $2.4(38)$ & 0.4 & 3.9 & 1.6 & $\mathrm{~Pb} / \mathrm{Zn}$ & $1.8(9)$ & 1.5 & 5.0 & 0.04 & $\mathrm{~Pb} / \mathrm{Zn}$ & $1.2(16)$ & 1.2 & 4.6 & 0.1 \\
\hline $\mathrm{Ag} / \mathrm{Bi}$ & 9.4 (17) & 9.3 & 40 & 0.7 & $\mathrm{Ag} / \mathrm{Bi}$ & $1.7(4)$ & 1.9 & 4.9 & 0.4 & $\mathrm{Ag} / \mathrm{Bi}$ & $5.3(9)$ & 6.8 & 20 & 0.5 \\
\hline $\mathrm{Pt} / \mathrm{Au}$ & 0.9 (4) & 0.4 & 1.3 & 0.2 & $\mathrm{Pt} / \mathrm{Au}$ & $0.3(1)$ & $\mathrm{NC}$ & $\mathrm{NC}$ & $\mathrm{NC}$ & $\mathrm{Pt} / \mathrm{Au}$ & $\mathrm{NC}$ & $\mathrm{NC}$ & $\mathrm{NC}$ & $\mathrm{NC}$ \\
\hline $\mathrm{Cu} / \mathrm{Pt}$ & 97 (11) & 79 & 257 & 2.0 & $\mathrm{Cu} / \mathrm{Pt}$ & 83 (7) & 144 & 426 & 0.7 & $\mathrm{Cu} / \mathrm{Pt}$ & $\mathrm{NC}$ & $\mathrm{NC}$ & $\mathrm{NC}$ & $\mathrm{NC}$ \\
\hline $\mathrm{Cu} / \mathrm{Au}$ & $254(11)$ & 504 & 1,821 & 5.8 & $\mathrm{Cu} / \mathrm{Au}$ & $1,315(6)$ & 1,055 & 3,028 & 3.5 & $\mathrm{Cu} / \mathrm{Au}$ & $1,681(12)$ & 2,930 & 9,760 & 15 \\
\hline
\end{tabular}

NA not analyzed, ND not detected in any inclusions $(3 \sigma$ limit of detection), NC not calculated ${ }^{\mathrm{a} C a l c u l a t e d}$ using measured inclusion salinity (microthermometric determination of final dissolution of halite) $)^{\mathrm{b}}$ Average concentration in " $n$ " analyzed inclusions that gave element concentrations above a $3 \sigma$ limit of detection (Individual detection limits for those inclusions not reported in the average values above are listed in Electronic Supplementary Material) ${ }^{\mathrm{c} C a l c u l a t e d}$ using measured inclusion salinity (microthermometric determination of final melting of halite) ${ }^{\mathrm{d}}$ Calculated using an estimated bulk salinity of $1.15 \mathrm{wt} \%$ eq. $\mathrm{NaCl}$ (see text for explanation) 
$35.1^{\circ} \mathrm{C}$ ) and $\mathrm{C}_{3} \mathrm{H}_{8}\left(96.7^{\circ} \mathrm{C}\right)$, their presence can raise the homogenization $T$ of the $\mathrm{P}_{\mathrm{CH} 4}$ and $\mathrm{S}_{\mathrm{CH} 4}$ inclusions above that for pure $\mathrm{CH}_{4}\left(-2.6^{\circ} \mathrm{C}\right)$. Thus, $\mathrm{S}_{\mathrm{CH} 4}$ inclusions probably contain the highest abundances of these additional compounds, as their behavior at low $T$ is least consistent with pure $\mathrm{CH}_{4}$.

\section{LA-ICP-MS analyses of single inclusions}

Table 2 summarizes average element concentrations in $50 \mathrm{P}_{\text {brine }}$ inclusions and $18 \mathrm{P}_{\mathrm{CH} 4}$ inclusions (from three groups of coeval $\mathrm{P}_{\text {brine }}+\mathrm{P}_{\mathrm{CH} 4}$ inclusions occurring in three different quartz crystals) and $19 \mathrm{~S}_{\text {halite }}$ inclusions from two different inclusion trails within a single quartz crystal. Also listed are the maximum and minimum concentrations for each element in each inclusion type, and a $1 \sigma$ standard deviation on the average concentration. Tables of all individual inclusion analyses (with microthermometry measurements) can be found in Electronic Supplementary Material associated with this article. Note that for many elements, the number of analyses represented in the average concentration is less than the total number of inclusions analyzed because not all elements were detected in the inclusions at a high confidence level $(3 \sigma)$. Also note that the detection limit for a given element is unique to each inclusion and related to inclusion size and ablation efficiency (i.e., the mass of inclusion contents analyzed over the ablation interval). For the $\mathrm{P}_{\text {brine }}$ and $\mathrm{S}_{\text {halite }}$ inclusions, the final halite dissolution or halite melting temperature was accurately determined for each inclusion individually prior to laser ablation, to obtain the $\mathrm{wt} \%$ eq. $\mathrm{NaCl}$ value required for quantification. However, to quantify element concentrations of $\mathrm{P}_{\mathrm{CH} 4}$ inclusions, the $\mathrm{wt} \%$ eq. $\mathrm{NaCl}$ values had to be estimated because no reliable salinity measurements could be obtained by microthermometry. Microthermometric measurements indicate that the minimum salinity of the aqueous fluid fraction was $\sim 23 \mathrm{wt} \%$ eq. $\mathrm{NaCl}$, based on the final melting of small ice dendrites on the walls of the $\mathrm{P}_{\mathrm{CH} 4}$ inclusions. Using a minimum salinity of $23 \mathrm{wt} \%$ eq. $\mathrm{NaCl}$ and an estimated volume fraction of aqueous fluid of 1-5 vol $\%$, the bulk salinity of the $\mathrm{P}_{\mathrm{CH} 4}$ inclusions was estimated to be between 0.23 and $1.15 \mathrm{wt} \%$ eq. $\mathrm{NaCl}$. This bulk salinity range was used to calculate the concentrations of all other elements in the $\mathrm{P}_{\mathrm{CH} 4}$ inclusions analyzed. In Table 2, the average composition of $\mathrm{P}_{\mathrm{CH} 4}$ inclusions was calculated using the higher bulk salinity of $1.15 \mathrm{wt} \%$ eq. $\mathrm{NaCl}$; however, the full data set (in Electronic Supplemental Material) lists all analyses calculated using both the 0.23 and $1.15 \mathrm{wt} \%$ eq. $\mathrm{NaCl}$ values for comparison. Considering that ice crystals were clearly visible in the inclusions during freezing measurements, and that such inclusions can easily contain up to $\sim 10 \mathrm{vol} \%$ aqueous fluid along their inner walls without the fluid being visible, the bulk salinity estimate of $1.15 \mathrm{wt} \%$ is tentatively considered most representative of the true bulk salinity of the aqueous fluid fraction in the $\mathrm{P}_{\mathrm{CH} 4}$ inclusions.
Analyses of $\mathrm{P}_{\text {brine }}$ inclusions show that $\mathrm{Ca}$ is the dominant cation, with $\mathrm{Na}$ and $\mathrm{K}$ also present in $\mathrm{wt} \%$ concentrations. Elements detected at concentrations in the thousands of ppm to wt \% range are $\mathrm{Pb}, \mathrm{Fe}, \mathrm{Mn}, \mathrm{Ba}$, $\mathrm{Zn}$ and $\mathrm{Sr}$. The presence of significant concentrations of these elements is consistent with the identification of the $\mathrm{Ca}-\mathrm{Na}-\mathrm{K}-\mathrm{Fe}-\mathrm{Mn}-\mathrm{Pb}-\mathrm{Ba}$ chloride daughter minerals in $\mathrm{P}_{\text {brine }}$ inclusions by other researchers (Farrow 1994; Molnar et al. 2001). Cu, Al, $\mathrm{Mg}, \mathrm{Rb}, \mathrm{B}, \mathrm{Sn}$ and $\mathrm{Li}$ are present in the brine in the 10-1,000 ppm range. Ag, Cs, $\mathrm{Pt}, \mathrm{Au}$ and $\mathrm{Bi}$ are present at concentrations in the 1$10 \mathrm{ppm}$ range. Notably, $\mathrm{Pt}$ and/or Au were detected in 11 of the brine inclusions (at a $3 \sigma$ confidence level), at concentrations ranging from 0.2 to $12 \mathrm{ppm}$. Ratios of $\mathrm{Pt} / \mathrm{Au}$ in the $\mathrm{P}_{\text {brine }}$ inclusions are around $\sim 1$. Most element ratios (e.g., $\mathrm{Pb} / \mathrm{Zn}$; Table 2) are very consistent from inclusion to inclusion; however, ratios involving the elements $\mathrm{Au}, \mathrm{Ag}, \mathrm{Pt}$, and $\mathrm{Bi}$ show up to an order of magnitude variation within the $\mathrm{P}_{\text {brine }}$ assemblage; for example, $\mathrm{Pt} / \mathrm{Au}$ ratios ranges from 0.2 to 1.3. Most variable are metal ratios involving $\mathrm{Cu} ; \mathrm{Cu}: \mathrm{Au}$ ratios which range from $\sim 6$ to $\sim 1,800$ within the inclusion populations analyzed.

Element concentrations in $\mathrm{P}_{\mathrm{CH} 4}$ inclusions (Table 2) are unremarkable. However, $\mathrm{Cu}, \mathrm{Ag}, \mathrm{Au}$ and $\mathrm{Bi}$ are present at concentrations comparable to or possibly higher than the coexisting $\mathrm{P}_{\text {brine }}$ inclusions, despite the much lower bulk salinity of the $\mathrm{CH}_{4}$ inclusions. Figure 10a shows the transient signal obtained during the ablation of a $\mathrm{Cu}, \mathrm{Au}, \mathrm{Bi}$, and $\mathrm{Ag}$-rich $\mathrm{P}_{\mathrm{CH} 4}$ inclusion (inclusion ju24a06; see full data set in Electronic Supplemental Material). Using the transient signal in Fig. 10a as an example, metal signals are clearly related to the $\mathrm{P}_{\mathrm{CH} 4}$ inclusion contents and are the result of host surface contamination. Other elements $(\mathrm{Na}, \mathrm{K}$, $\mathrm{Ca}, \mathrm{Mn}, \mathrm{Fe}, \mathrm{Pb}$ and $\mathrm{Zn}$ ) show no relative enrichment in the $\mathrm{P}_{\mathrm{CH} 4}$ inclusions. This observation is illustrated graphically in Fig. 11a in which the average element concentrations (solid circles) and ranges in concentration (black bar) in all $\mathrm{P}_{\mathrm{CH} 4}$ inclusions analyzed are plotted against the respective element concentrations (average and range) of $\mathrm{P}_{\text {brine }}$ inclusions [Mean element concentrations in the $\mathrm{P}_{\mathrm{CH} 4}$ inclusions are those calculated assuming a bulk salinity of $1.15 \mathrm{wt} \%$ eq. $\mathrm{NaCl}$ ( $5 \mathrm{vol} \%$ brine at $\sim 23 \mathrm{wt} \%$ eq. $\mathrm{NaCl}$ )]. Inset Fig. $11 \mathrm{~b}$ shows the shift in average element concentration for $\mathrm{Cu}$ and $\mathrm{Zn}$ in $\mathrm{P}_{\mathrm{CH} 4}$ inclusions if a bulk salinity of $0.23 \mathrm{wt} \%$ eq. $\mathrm{NaCl}$ is used $(1 \mathrm{vol} \%$ brine at $\sim 23 \mathrm{wt} \%$ eq. $\mathrm{NaCl}$ ). The solid diagonal line in Fig. $11 \mathrm{a}, \mathrm{b}$ corresponds to equal element concentrations in the $\mathrm{P}_{\text {brine }}$ and $\mathrm{P}_{\mathrm{CH} 4}$ inclusions $\left(C_{\text {brine }}=C_{\mathrm{CH} 4}\right)$; degrees of element fractionation are shown as dotted lines corresponding to lines of constant $C_{\text {brine }} / C_{\mathrm{CH} 4}$ for each element. In Fig. 11a, Ca, Na, K, Fe, Mn, $\mathrm{Zn}$ and $\mathrm{Pb}$ behave similarly and are always strongly enriched in the brine phase relative to the hydrocarbon fluid (mean $C_{\text {brine }} / C_{\mathrm{CH} 4}=\sim 30$ to 100 ; range $=\sim 10$ to 1,000$)$. Au, $\mathrm{Bi}$ and $\mathrm{Ag}$ behave differently from the strongly brinepartitioning elements; they may be variably enriched in 
Fig. 10 Transient LA-ICP-MS intensity plots of inclusion ablations. a Ablation of a $\mathrm{P}_{\mathrm{CH} 4}$ inclusion (inclusion \# ju24a06; see Electronic Supplementary Material). Background is collected with the laser off for at least $50 \mathrm{~s}$. The laser is switched on, monitored by the increase in the $\mathrm{Si}^{29}$ (grey line) count rate. At $t \sim 60 \mathrm{~s}$ the inclusion is opened (increase in $\mathrm{Na}^{23}$ signal; white diamonds) and the pit diameter increased sequentially (corresponding to the two short drops in count rate). A mixed signal (inclusion + host) is observed for $\mathrm{Si}^{29}, \mathrm{Na}^{23}, \mathrm{Cu}^{65}$ (grey squares), $\mathrm{Ag}^{107}$ (dark grey triangles), $\mathrm{Bi}^{209}$ (crosses), and $\mathrm{Au}^{197}$ (solid black circles) over a $\sim 20$ s interval. Note the typically irregular signal for $\mathrm{Au}^{197}$ showing several isolated counting events which roughly coincide with the $\mathrm{Cu}^{65}$ signal. B. Ablation of a $\mathrm{S}_{\text {halite }}$ inclusion (inclusion \# de16a07; see Electronic Supplementary Material). The inclusion is opened at $\sim 120$ s. Note the increase in $\mathrm{Pt}^{195}$ (solid black circles) counting events at the beginning and end of the inclusion signal. Also note the coincidence between the count rates for $\mathrm{Cu}^{65}$ (grey squares) $\mathrm{Li}^{7}$ (grey triangles) and $\mathrm{Na}^{23}$ (white diamonds)
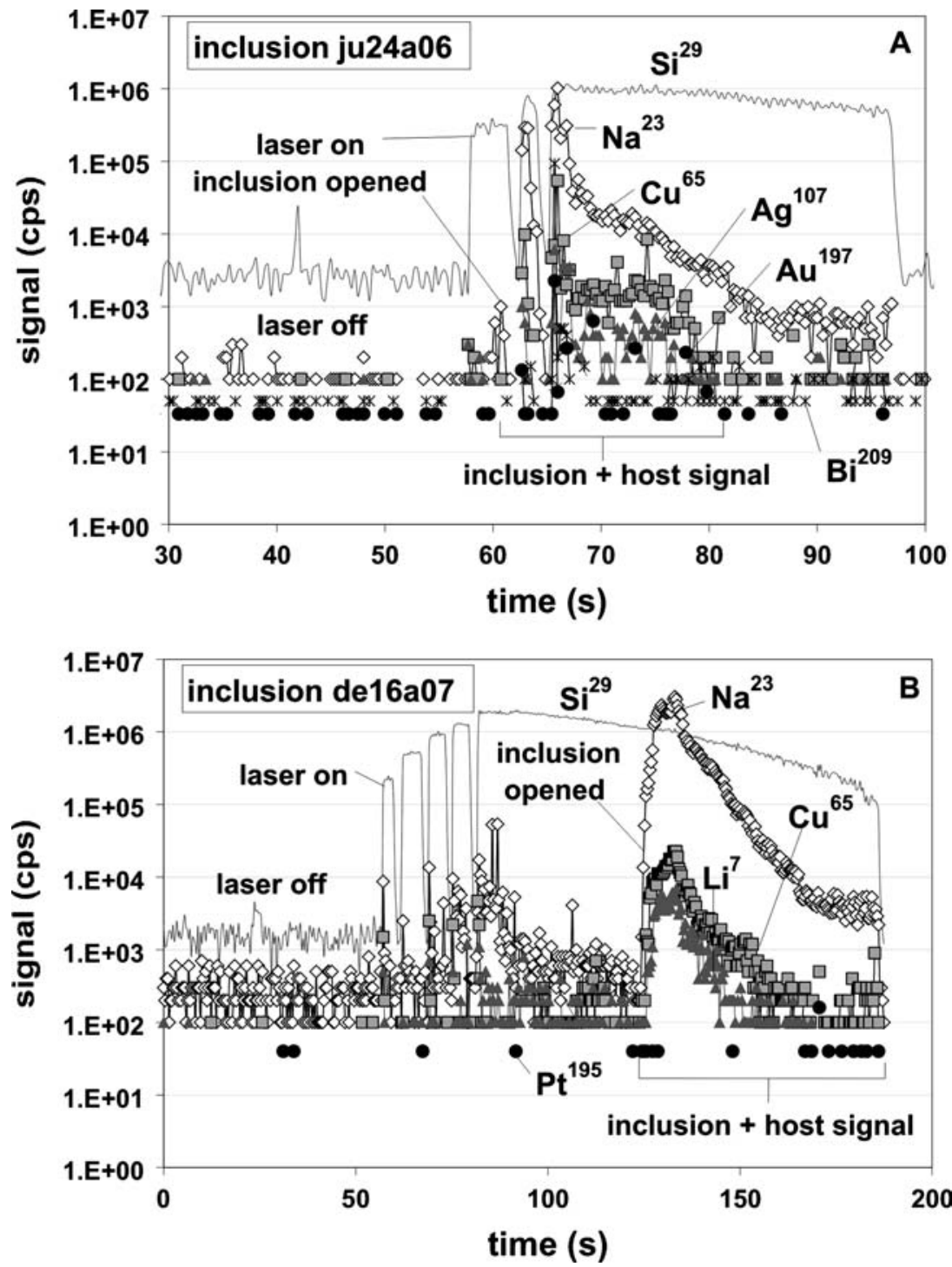

either the brine or $\mathrm{CH}_{4}$ phase based on the range of concentrations measured and calculated (mean $C_{\text {brine }}$ $\mathrm{C}_{\mathrm{CH} 4}=\sim 0.8$ to 2 ; range $=\sim 0.07$ to 40 ). $\mathrm{Cu}$ is commonly fractionated into the $\mathrm{CH}_{4}$ phase $\left(C_{\text {brine }} /\right.$ $C_{\mathrm{CH} 4}=\sim 0.1$; range $=\sim 0.006-10$ ). It is important to note that changes in the assumed bulk salinity of the $\mathrm{P}_{\mathrm{CH} 4}$ inclusions will change the calculated individual element concentration ratios between brine and $\mathrm{CH}_{4}$ (Table 2, Fig. 11a, b) will change. Therefore, in the absence of an accurate bulk salinity determination for the $\mathrm{P}_{\mathrm{CH} 4}$ inclusions, it is not possible to demonstrate for certain that specific ore metals (e.g., $\mathrm{Cu}$ ) occur in greater absolute concentration in the $\mathrm{CH}_{4}$ phase than in the brine. However, changing the bulk salinity estimate of the $\mathrm{P}_{\mathrm{CH} 4}$ inclusions does not change the relative partitioning behavior of the elements analyzed; element concentration ratios between $\mathrm{CH}_{4}$ and brine for $\mathrm{Cu}, \mathrm{Au}, \mathrm{Bi}$ and $\mathrm{Ag}$ are greater than those for $\mathrm{Na}$, $\mathrm{Ca}, \mathrm{Fe}, \mathrm{Mn}, \mathrm{Pb}$ and $\mathrm{Zn}$, regardless of the uncertainty in absolute element concentration. To eliminate uncertainties in the accidental brine content and bulk salinity of the $\mathrm{P}_{\mathrm{CH} 4}$ inclusions, metal enrichment in the $\mathrm{CH}_{4}$ relative to the brine may also be expressed in a ratio normalized to $\mathrm{Na}$ (Heinrich et al. 1999). For example, in (coeval) group 1 of $\mathrm{P}_{\mathrm{CH} 4}$ and $\mathrm{P}_{\text {brine }}$ inclusions (Appendix 4), the average metal enrichment ratios $\left[\left(\right.\right.$ metal $\left._{\mathrm{CH} 4} / \mathrm{Na}_{\mathrm{CH} 4}\right) /\left(\right.$ metal $\left.\left._{\text {brine }} / \mathrm{Na}_{\text {brine }}\right)\right]$ are as follows: $\mathrm{Ca}=1.8, \mathrm{~K}=1.4, \mathrm{Mn}=0.7, \mathrm{Fe}=0.7, \mathrm{~Pb}=0.7, \mathrm{Zn}=3.0$, $C u=460.9, A g=54.8, A u=11.5, B i=36.5$. The relative tendency for elements to fractionate preferentially into $\mathrm{CH}_{4}$ phase appears to be: $\mathrm{Cu}$ (strongly fractionated into the $\left.\mathrm{CH}_{4}\right)>\mathrm{Ag}, \mathrm{Bi}>\mathrm{Au}>>\mathrm{Ca}, \mathrm{Na}, \mathrm{K}, \mathrm{Fe}$, $\mathrm{Pb}, \mathrm{Zn}, \mathrm{Mn}$ (strongly fractionated into the brine).

$S_{\text {halite }}$ inclusions (Table 2) are composed primarily of $\mathrm{NaCl}$, with minor amounts of $\mathrm{Ca}$ (up to $\sim 3 \mathrm{wt} \%$ ) and $\mathrm{Fe}$ (up to $\sim 4 \mathrm{wt} \%$ ). Figure $10 \mathrm{~b}$ shows the transient signal obtained during the ablation of a $\mathrm{S}_{\text {halite }}$ inclusion (inclusion de16a07; see full data set in Electronic Supplementary Material). X-ray mapping (by SEM-EDS) of halite inclusions confirmed that the $\mathrm{Ca}$ is present in the 


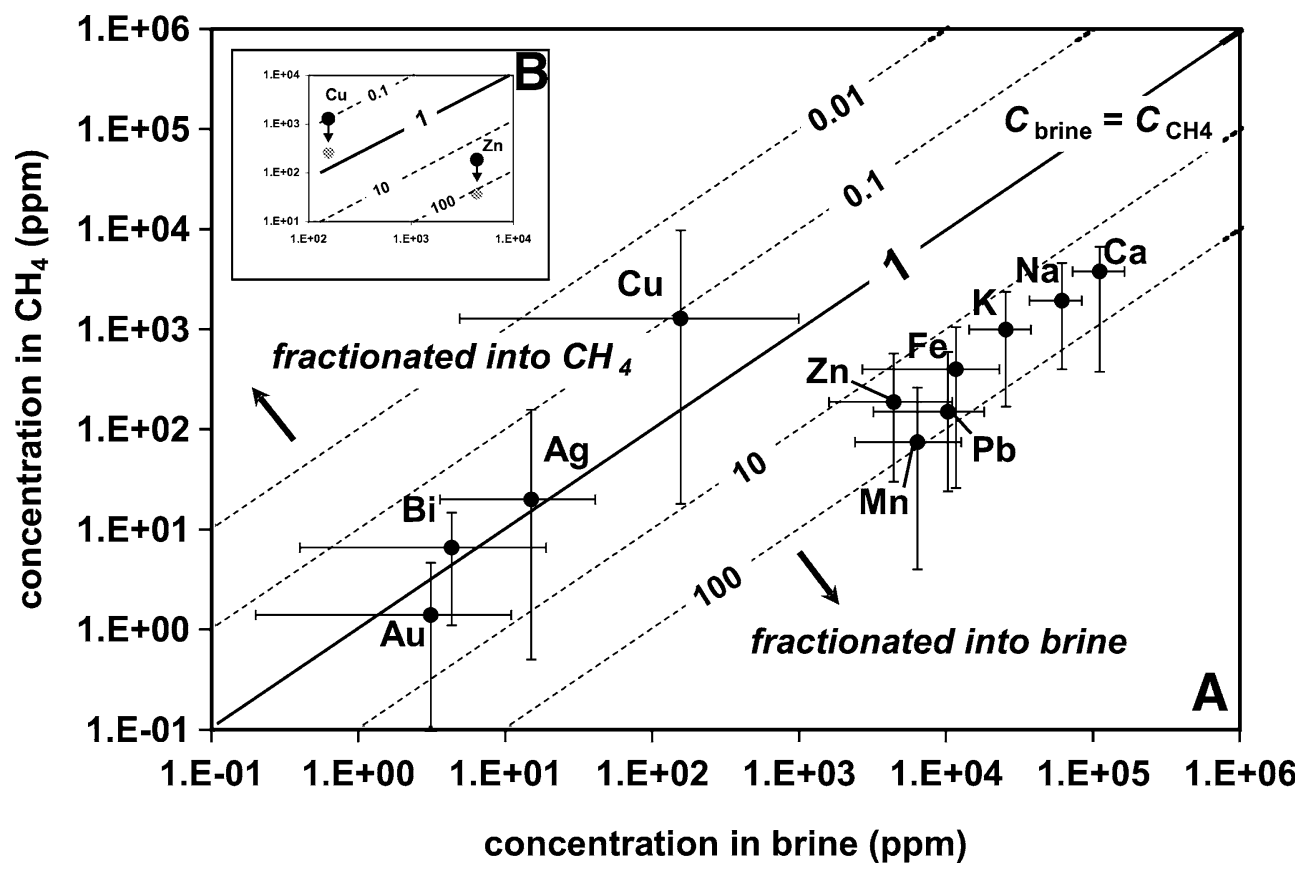

Fig. 11 Element concentrations in coexisting $\mathrm{P}_{\text {brine }}$ and $\mathrm{P}_{\mathrm{CH} 4}$ inclusions. Diagonal lines represent constant ratios of $C_{\mathrm{brine}}^{\text {elem }} / C_{\mathrm{CH}_{4}}^{\mathrm{elem}}$ as labeled. The diagonal solid line represents equal distribution of an element between the two inclusion types (no fractionation; $C_{\text {brine }}^{\text {elem }} / C_{\mathrm{CH}_{4}}^{\text {elem }}=1$ ). a Black solid circles are average element concentrations. Error bars indicate the range of concentrations for each element from inclusions containing either $\mathrm{CH}_{4}$ or brine. Mean concentrations are based on the approximation of a bulk salinity of $1.15 \mathrm{wt} \%$ eq. $\mathrm{NaCl}(5 \mathrm{vol} \%$ aqueous film at $\sim 23 \mathrm{wt} \%$ $\mathrm{NaCl}$ ) in the $\mathrm{P}_{\mathrm{CH} 4}$ inclusions. b Demonstration of the effect of lowering the assumed bulk salinity from 1.15 (black solid circles) to $0.23 \mathrm{wt} \%$ eq. $\mathrm{NaCl}$ (grey solid circles; $1 \mathrm{vol} \%$ aqueous film) on the mean concentrations of $\mathrm{Cu}$ and $\mathrm{Zn}$ in $\mathrm{P}_{\mathrm{CH} 4}$ inclusions. $\mathrm{Cu}, \mathrm{Ag}, \mathrm{Bi}$ and $\mathrm{Au}$ are enriched in the $\mathrm{P}_{\mathrm{CH} 4}$ inclusions (show lower $C_{\text {brine }}^{\text {elem }} / C_{\mathrm{CH}_{4}}^{\text {elem }}$ ratios) relative to strongly brine-partitioning elements showing very similar behavior ( $\mathrm{Na}, \mathrm{Ca}, \mathrm{Fe}, \mathrm{Mn}, \mathrm{Zn}, \mathrm{Pb}$ ). Using the $1.15 \mathrm{wt} \%$ eq. $\mathrm{NaCl}$ bulk salinity approximation, many $\mathrm{P}_{\mathrm{CH} 4}$ inclusions have absolute concentrations of $\mathrm{Cu}, \mathrm{Ag}, \mathrm{Bi}$ and $\mathrm{Au}$ higher than the coexisting $\mathrm{P}_{\text {brine }}$ population

subsidiary amounts of aqueous fluid surrounding the halite, rather than as a component in the halite (i.e., in solid solution; Fig. 12). The $\mathrm{Cu}$ content of the $\mathrm{S}_{\text {halite }}$ inclusions is commonly very high (average $=4,486 \mathrm{ppm} \mathrm{Cu}$; range $17 \mathrm{ppm}$ to over $1 \mathrm{wt} \% \mathrm{Cu}$; $n=14$ ). Lithium contents are also very high (average $=978 \mathrm{ppm} \mathrm{Li}$; range $4-2,850 \mathrm{ppm}$ ) and correlate with $\mathrm{Cu}$ concentration. The $\mathrm{Cu}$ and $\mathrm{Li}$ appear to be dissolved in the halite itself rather than in the subsidiary amount of aqueous fluid surrounding the halite (Fig. 10b). Other elements (Mn, K, Zn, Sr, Ba) were detected in the 10-100 ppm range and are probably present in the aqueous fluid surrounding the halite rather than in the halite itself. Several element ratios (e.g., $\mathrm{Pb}: \mathrm{Zn})$ in the $\mathrm{P}_{\text {brine }}$ and $\mathrm{S}_{\text {halite }}$ inclusions are comparable (Table 2), despite the overall much lower concentrations of these elements in the $\mathrm{S}_{\text {halite }}$ inclusions. Significant ( $\mathrm{ppm}$ ) concentrations of $\mathrm{Pt}$ and $\mathrm{Au}$ were detected in five of the halite-melt inclusions analyzed.

\section{Discussion}

Origin of the brine- $\mathrm{CH}_{4}$ assemblage

The occurrence of inclusions containing $\mathrm{CH}_{4}$, brine and $\mathrm{CH}_{4}$-brine mixtures within a single, coeval assemblage suggests the entrapment of immiscible fluid phases. At $\sim 35 \mathrm{wt} \% \mathrm{NaCl}$ (comparable to the brine salinity in this study) and at a $\mathrm{P}_{\text {trapping }}$ of $1.1-1.5 \mathrm{kbar}$ (for $\mathrm{P}_{\text {brine }}$ inclusions occurring without coexisting $\mathrm{P}_{\mathrm{CH} 4}$ inclusions; Molnar et al. 2001), the two-phase field in the $\mathrm{CO}_{2}$ $\mathrm{NaCl}-\mathrm{H}_{2} \mathrm{O}$ system extends to $\sim 680^{\circ} \mathrm{C}$ and probably higher $\left(>700^{\circ} \mathrm{C}\right.$ ) in the $\mathrm{CH}_{4}-\mathrm{NaCl}-\mathrm{H}_{2} \mathrm{O}$ system (Krader and Franck 1987). Graphically (Fig. 13), we estimate by the intersection of brine and $\mathrm{CH}_{4}$ isochores that the pressure of entrapment for the $\mathrm{P}_{\text {brine }}+\mathrm{P}_{\mathrm{CH} 4}$ assemblage could not have exceeded $\sim 500$ bars, a pressure considerably lower than the estimate of Molnar et al. (2001). At such a low pressure of entrapment, two immiscible fluid phases would have certainly coexisted (Bowers and Helgeson 1983; Krader and Franck 1987). On the basis of our trapping pressure estimate, the $\mathrm{CH}_{4}$ may have been a minor dissolved component in the original one-phase brine phase (Molnar et al. 2001) that later separated from the brine during local decompression during vein formation. Alternately, simple cooling of a $\mathrm{CH}_{4}$-bearing brine as it came into contact with groundwater or wall rocks, or a combination of both decompression and cooling could have been responsible for $\mathrm{CH}_{4}$-brine unmixing.

Compositional data (Table 2) allow further constraints on the origin of the brine. The mean $\mathrm{Ca}: \mathrm{Na}$ ratio in the $\mathrm{P}_{\text {brine }}$ inclusions is $1.9 \pm 0.7(1 \sigma, n=50)$; this value is comparable to the range in $\mathrm{Ca}: \mathrm{Na}$ ratios obtained from saline groundwaters sampled at a compa- 

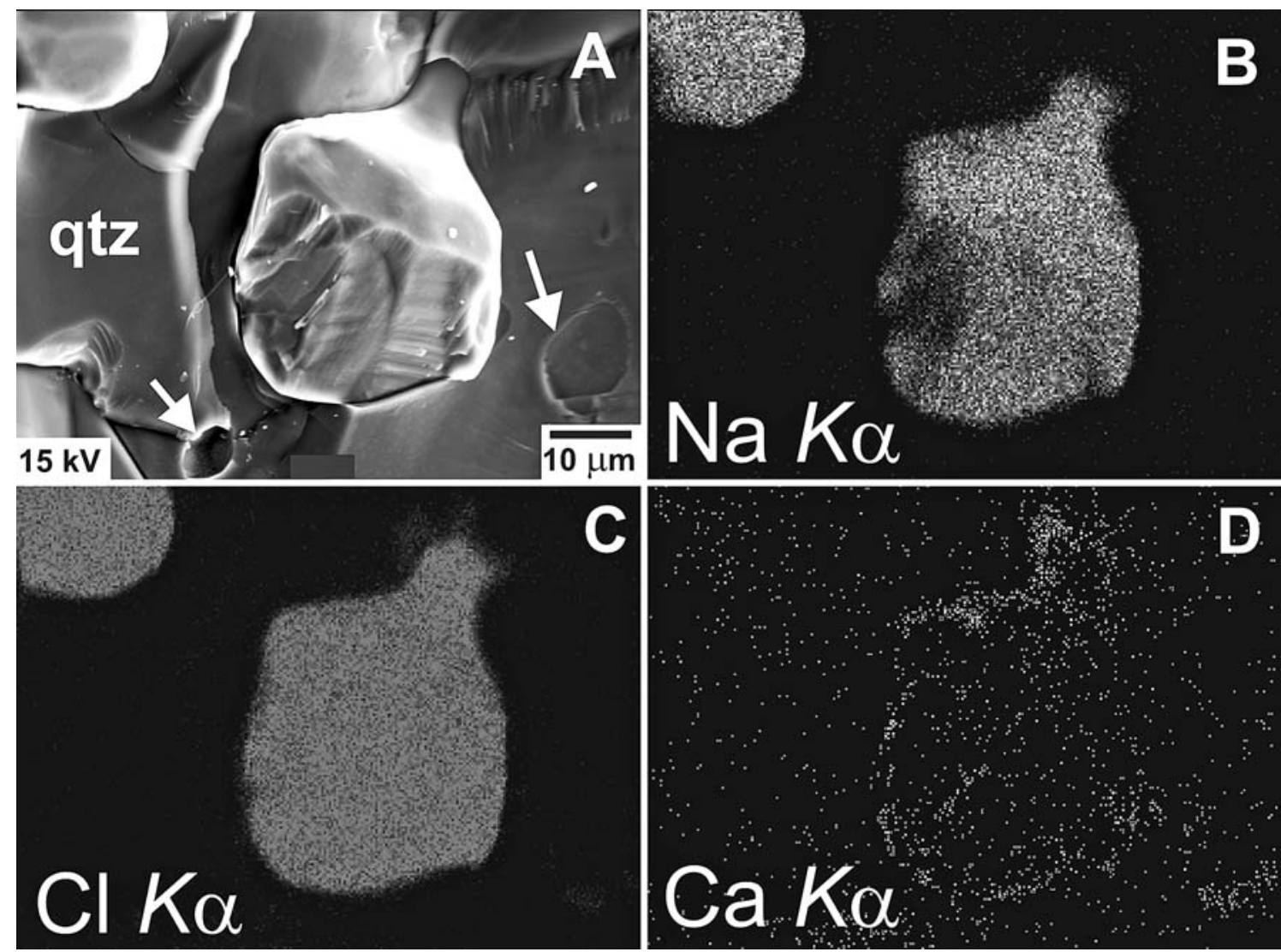

Fig. 12 Secondary electron and X-ray intensity images of a halide melt inclusion. a Secondary electron image showing opened solid inclusions of halide-melt (center and upper left) on a fractured surface in quartz (qtz); opened $\mathrm{CH}_{4}$ inclusions (arrows) are also visible. b $\mathrm{Na} K \alpha, \mathbf{c} \mathrm{Cl} K \alpha, \mathbf{d} \mathrm{Ca} K \alpha$ showing a halo of elevated X-ray intensity along the margin of the melt inclusion, corresponding to dried aqueous fluid that surrounded the solid melt in the unopened inclusion at room temperature

rable sample depth $(\sim 1,100 \mathrm{~m})$ at the Fraser Mine $(\mathrm{Ca}: \mathrm{Na}$ ratio $=1.7-1.9 ;$ Frape and Fritz 1982), strengthening previous suggestions that the brine is compositionally related to deep groundwaters (i.e., formation waters with compositions that have remained relatively unchanged since their formation) have $\mathrm{Sr}: \mathrm{Rb}$ ratios in the brine [mean $=40 \pm 5(1 \sigma$, $n=50)$ ] strongly reflect interaction with the gneissic host rocks in the study area which have an average bulk rock Sr:Rb ratio of $\sim 39$ (Hanley 2002). However, the brine composition has been modified to contain other cations (e.g., $\mathrm{Fe}, \mathrm{Mn}, \mathrm{Pb}, \mathrm{Ba}$ ) in wt $\%$ concentrations and significant concentrations of ore metals $(\mathrm{Cu}, \mathrm{Ag}, \mathrm{Bi}, \mathrm{Pt}, \mathrm{Au})$. For comparison, $\mathrm{Fe}, \mathrm{Mn}, \mathrm{Pb}$ and $\mathrm{Ba}$ are present only in trace $(<10 \mathrm{ppm})$ concentrations in the deep groundwaters of the Sudbury area (Frape and Fritz 1982) and the ore metals detected in the $P_{\text {brine }}$ inclusions could clearly not have been derived from the groundwaters. Therefore, models describing the interaction of heated groundwater with sulfide, or mixing of groundwater with a second fluid of magmatic origin exsolved from the SIC or from a sulfide liquid are

supported by our new observations (Li 1993; Farrow 1994; Marshall et al. 1999; Hanley et al. 2004).

Origin of the halite- $\mathrm{CH}_{4}, \mathrm{C}_{2} \mathrm{H}_{6}-\mathrm{C}_{2} \mathrm{H}_{2}, \mathrm{C}_{3} \mathrm{H}_{8}$ assemblage

Single inclusions containing the proposed halide-melt and hydrocarbon phases exhibit highly variable halite:hydrocarbon ratios, suggesting that the hydrocarbon phase and halide-melt coexisted (immiscibly) at the time of entrapment. No previous studies have reported the occurrence of hydrocarbon or solid halite inclusions associated with the Sudbury Igneous Complex or its ore deposits. Although carbonic fluid-halide melt assemblages have been reported in a few other mafic-intermediate igneous systems (e.g., Laramie Anorthosite Complex; Frost et al. 1989), none have been reported which contain pure hydrocarbon fluids (i.e., with no $\mathrm{CO}_{2}$ present). On the basis of their noncubic and commonly irregular morphology, narrow range of melting temperatures and a lack of any significant amount of aqueous fluid, the $S_{\text {halite }}$ inclusions do not appear to represent accidentally trapped inclusions of halite precipitated from a halite-saturated aqueous fluid (e.g., Erwood et al. 1979). Furthermore, it is unlikely that halite precipitated from an aqueous fluid could accommodate such high concentrations of $\mathrm{Cu}$ dissolved in its structure (Fig. 10b), owing to the significant difference in size between the $\mathrm{Cu}^{1+}$ and $\mathrm{Na}^{1+}$ ions in sixfold coordination (Shannon 1979). The 


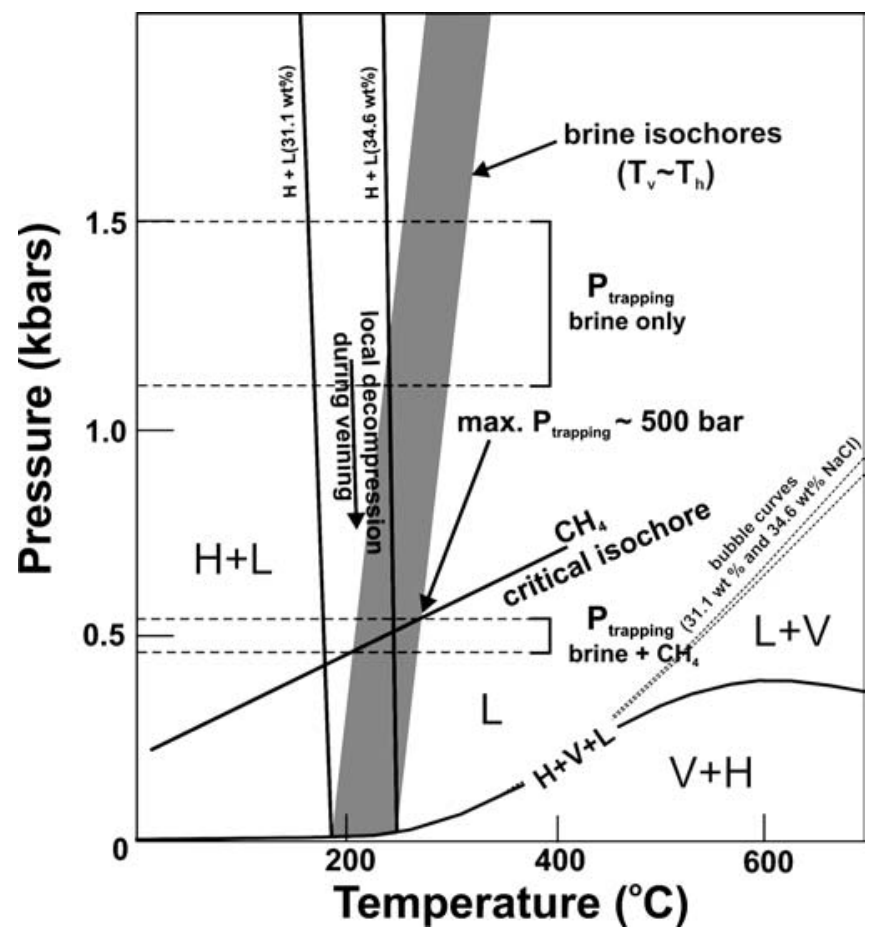

Fig. 13 Estimation of the pressure of entrapment of the primary $\mathrm{P}_{\text {brine }}+\mathrm{P}_{\mathrm{CH} 4}$ inclusion assemblage using intersecting isochores on a pressure-temperature section for the $\mathrm{NaCl}-\mathrm{H}_{2} \mathrm{O}$ system (position of relevant fields and phase boundaries taken from Sourirajan and Kennedy 1962; Bodnar 1994; Atkinson 2002). Note that the determination of pressure of entrapment for the $\mathrm{P}_{\text {brine }}+\mathrm{P}_{\mathrm{CH} 4}$ inclusion assemblage is an approximation only because we have applied isochore calculations for the pure $\mathrm{NaCl}-\mathrm{H}_{2} \mathrm{O}$ system to a complex mixed salt system. Isochores for the coexisting $\mathrm{P}_{\text {brine }}$ inclusions cannot be determined for the majority of inclusions because the inclusions homogenize by halite dissolution and vapor disappearance temperatures are considerably lower than $T_{\mathrm{h}}$; for those inclusions, isochores in the $\mathrm{H}+\mathrm{L}$ field of the $\mathrm{NaCl}-\mathrm{H}_{2} \mathrm{O}$ system are not constrained. However, $T_{\mathrm{v}} \approx T_{\mathrm{h}}$ in several inclusions (inclusion \#s ju22a07, ju22a08, ju22a10, ss02a03, ss03a04 and ss03b07; see Electronic Supplementary Material). Isochores for the listed inclusions originate near the intersection of the halite liquidi and bubble curves (for inclusions ranging from $31.1 \mathrm{wt} \%$ and $34.63 \mathrm{wt} \%$ eq. $\mathrm{NaCl}$ ) and lie primarily in the L-only field. For the listed inclusions, isochores were calculated using Eq. 12 from Zhang and Franz (1987), the inclusion salinities, and values of $T_{\mathrm{h}}$; the isochores define the grey field labeled "brine isochores". Most $\mathrm{P}_{\mathrm{CH} 4}$ inclusions homogenized by critical behavior near the critical $T$ for pure $\mathrm{CH}_{4}\left(-2.6^{\circ} \mathrm{C}\right)$; the density of the $\mathrm{CH}_{4}$ phase is close to critical density $(0.162 \mathrm{~g} / \mathrm{mL})$ and the isochore for the $\mathrm{CH}_{4}$ phase is relatively shallow (labeled "methane critical isochore"). The maximum pressure of entrapment $\left(\mathrm{P}_{\text {trapping }}\right)$ for those inclusions is constrained by the intersection of the critical $\mathrm{CH}_{4}$ isochore with the brine inclusion isochores and is $\sim 500$ bar. For comparison, the range of $P_{\text {trapping }}(1.1-1.5 \mathrm{kbar})$ for the primary assemblage where the assemblage contains only the brine phase (Molnar et al. 2001). This would suggest that a minimum fluid decompression of $\sim 600$ bar resulted in brine- $\mathrm{CH}_{4}$ immiscibility

petrographic, microthermometric and compositional characteristics of $S_{\text {halite }}$ inclusions all suggest that the $S_{\text {halite }}$ inclusions represent trapped amounts of a halide melt (molten salt) phase which contained a small amount of dissolved $\mathrm{H}_{2} \mathrm{O}$ and other trace cations at the time of entrapment.
While the occurrence of a halide-melt phase is plausible, the coexistence of a $\mathrm{CO}_{2}$-free hydrocarbon fluid with a halide-melt is problematic: $\mathrm{A} \mathrm{CH}_{4}$-dominant, $\mathrm{C}-$ $\mathrm{O}-\mathrm{H}$ gas phase $\left(>95 \mathrm{~mol} \% \mathrm{CH}_{4}\right.$ ) should exist stably at halide-melt entrapment temperatures $\left(\sim 700-800^{\circ} \mathrm{C}\right)$ only at unrealistically reducing conditions (QFM-4; ironwustite buffer; Mathez et al. 1989). The presence of magnetite in massive sulfides from the footwall ore zones suggests that the sulfide liquids crystallized along a magnetite-saturated liquidus; therefore, the ambient $f \mathrm{O}_{2}$ conditions in the vicinity of the crystallizing sulfides could not have been as reducing as QFM-4. At such temperature and moderate $f \mathrm{O}_{2}$, the dominant $\mathrm{C}-\mathrm{O}-\mathrm{H}$ species in the inclusions should be $\mathrm{CO}_{2}$ (Salvi and Williams-Jones 1997; Potter and Konnerup-Madsen 2003). Additionally, the higher hydrocarbons in the $\mathrm{S}_{\mathrm{CH} 4}$ inclusions would be expected to convert completely to graphite above $500^{\circ} \mathrm{C}$ in contact with a halide-melt phase (Shock 1990). In response to these problems, it is possible that the carbonic fluid coexisting with the halide-melt phase was originally $\mathrm{CO}_{2}$-dominant at magmatic temperatures but was later converted to a $\mathrm{CH}_{4}+\mathrm{C}_{2} \mathrm{H}_{6}-\mathrm{C}_{2} \mathrm{H}_{2}+\mathrm{C}_{3} \mathrm{H}_{8}$ fluid prior to entrapment by some disequilibrium process (i.e., Fischer-Tropsch synthesis; Salvi and Williams-Jones 1997) or that the hydrocarbons survived in a metastable state long enough to be preserved in fluid inclusions. The presence of higher order hydrocarbons preserved in kimberlite pipes (Shepeleva et al. 1990) and mantle xenoliths (Mathez 1987; Sugisaki and Mimura 1994) would suggest that such compounds may survive at magmatic conditions for sufficient periods of time to be trapped within inclusions.

The sulfide ores are a favorable source for a halidemelt phase considering that: (1) $S_{\text {halite }}$ inclusions occur only in close proximity (within a few meters) to massive sulfide ores and do not occur in the "background" fluid inclusion record in the Levack Gneiss (Molnar et al. 2001), (2) the $\mathrm{S}_{\text {halite }}+\mathrm{S}_{\mathrm{CH} 4}$ assemblage and sulfide minerals texturally postdate the lower temperature $\mathrm{P}_{\text {brine }}+\mathrm{P}_{\mathrm{CH} 4}$ assemblage hosted in early alteration quartz, and (3) $\mathrm{S}_{\text {halite }}$ inclusions contain abundant $\mathrm{Cu}$ and precious metals. The exsolution of halide-melt and hydrocarbon phases from crystallizing sulfides would imply that $\mathrm{Cl}$, alkali metals (mainly $\mathrm{Na}$ ), and $\mathrm{C}$ were dissolved (compatible) elements in the original sulfide liquid. Although the solubilities of $\mathrm{Cl}, \mathrm{Na}$ and $\mathrm{C}$ in $\mathrm{Cu}-$ rich sulfide liquids are not known, trace amounts of these elements should eventually reach saturation and be ultimately rejected as the sulfide liquid reaches its solidus temperature. (Note that Li (1993) originally suggested that the sulfide-exsolved phase was the primary brine. However, we conclude from textural observations that final crystallization of the sulfides post-dated the entrapment of the primary brine). Unfortunately, inclusions of solid halite were not observed in any sulfide minerals in this study. However, there are several other indications that the fractionated $\mathrm{Cu}-\mathrm{Fe}$-sulfide liquids may have contain significant dissolved $\mathrm{Cl}$. At the Fraser 


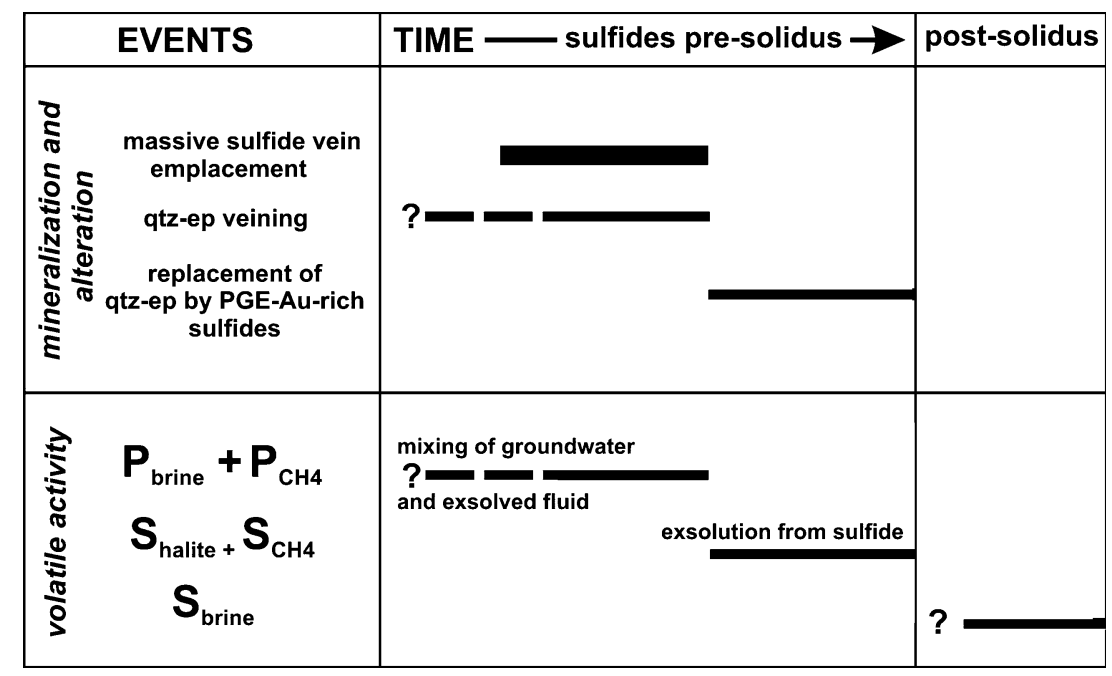

Fig. 14 Tentative paragenetic sequence for hydrothermal/volatile events identified in this study. The formation of quartz-epidote veins, deposition of $\mathrm{Au}$ in the veins in association with the silicates and entrapment of primary fluid inclusions containing brine $\left(\mathrm{P}_{\text {brine }}\right)$ and $\mathrm{CH}_{4}\left(\mathrm{P}_{\mathrm{CH} 4}\right)$ coincided with or preceded footwall sulfide vein emplacement (timing depends partly on the interpreted source of the brine; see text for description) During the final stages of sulfide fractionation and crystallization, PGE-Au-rich sulfides migrated into the earlier-formed quartz-epidote veins and replaced the silicates; metal-rich halide-melt $\left(\mathrm{S}_{\text {halite }}\right)$ and hydrocarbons $\left(\mathrm{S}_{\mathrm{CH} 4}\right)$ exsolved from the sulfides as the sulfides approached their solidus temperature. Late-stage brines circulated through the study area after the ores had solidified and cooled

mine, lawrencite $\left(\mathrm{FeCl}_{2}\right)$, bismoclite $(\mathrm{BiOCl})$, ferropyrosmalite $\left[\left(\mathrm{Fe}^{2+}, \mathrm{Mn}\right)_{8} \mathrm{Si}_{6} \mathrm{O}_{15}(\mathrm{OH}, \mathrm{Cl})_{10}\right]$, and unnamed $\mathrm{Pd}$-Bi-chlorides occur as solid inclusions (formerly, phenocrysts) within massive sulfides in the footwall (Li 1993; Farrow 1994; Hanley 2002). Recently, Mungall and Brenan (2003) confirmed field observations of the apparently chalcophile nature of the halogens by dissolving $\mathrm{wt} \%$ concentrations of $\mathrm{Cl}\left(\mathrm{as}_{\mathrm{FeCl}}\right)$ in sulfide liquid using a piston cylinder apparatus; they observed that the sulfides exsolved Si-rich, Fe-halide salts during quench. In other mafic systems, $\mathrm{Cu}$-bearing halide-melt phases coexisted with stable sulfide liquid. For example, Renno et al. (2004) reported coexisting $\mathrm{Cu}$-sulfide, $\mathrm{Cu}-$ chloride, and silicate glass within magnesiohastingsite cumulates at the TUBAF seamount, Papua New Guinea and argued that the unmixing of a complex $\mathrm{Cu}$-bearing chloride-melt from mafic silicate liquid occurred at magmatic temperatures $\left(>800^{\circ} \mathrm{C}\right)$.

It is possible that our interpretation of the origin of $\mathrm{S}_{\text {halite }}$ inclusions as a trapped halide-melt phase is incorrect and that the inclusions do represent accidentally trapped halite crystals precipitated from a much lower- $T$, halite-saturated fluid. The halite-saturated fluid was not aqueous in composition for the reasons discussed above. Rather, halite may have been precipitated along the walls of fractures in the quartz by a $\mathrm{NaCl}-$ saturated hydrocarbon fluid at lower $T\left(<500^{\circ} \mathrm{C}\right)$ and more geologically realistic $f_{2}$ which would favor the stability of $\mathrm{CH}_{4}$ and other hydrocarbons as the dominant equilibrium species. If, on cooling, a hydrocarbon fluid phase precipitated $\mathrm{NaCl}$, the result would be a mixed assemblage of inclusions containing accidentally trapped halite, hydrocarbon fluid, or variable amounts of halite + hydrocarbon fluid (consistent with the observed assemblage). Although the solubility of $\mathrm{NaCl}$ in a non-polar solvent such as $\mathrm{CH}_{4}$ or $\mathrm{CO}_{2}$ has not been investigated at any $P-T$ conditions (for all practical purposes, $\mathrm{CH}_{4}$ and $\mathrm{NaCl}$ may be considered to be mutually immiscible phases), a non-polar fluid can probably carry trace quantities of $\mathrm{NaCl}$ at lower temperatures $\left(\sim 300-500^{\circ} \mathrm{C}\right.$; Bowers and Helgeson 1983).

\section{Relative timing of ore and volatile formation}

Volatile evolution and magmatic sulfide differentiation were clearly part of a single, continuous process in the Sudbury footwall. On the basis of our new observations, metal transport and redistribution by volatiles occurred twice during the evolution of the footwall ore systems. Figure 14 and the summary below present an interpretation of the relative timing of volatile events in the footwall environment in relation to ore deposition, based on our new observations: Since the $\mathrm{P}_{\text {brine }}+\mathrm{P}_{\mathrm{CH} 4}$ assemblage predates (texturally) the last stages of sulfide crystallization in the alteration veins, it is clear that hydrosaline fluids were present in the footwall immediately prior to or during massive sulfide vein emplacement (pre-solidus; Fig. 14). After the formation of the metal-rich brine (i.e., by mixing of groundwater with a magmatic ore fluid), the brine entered the footwall environment via structural pathways (Sudbury Breccia zones) and exsolved an immiscible $\mathrm{CH}_{4}$ phase during local decompression during vein formation or by cooling of the brine as it came into contact with the host vein wall rocks. Phase separation may have been responsible for some Au precipitation in the alteration veins (Naden and Shepherd 1989). In addition to precipitating Au, phase separation caused $\mathrm{Cu}, \mathrm{Au}, \mathrm{Ag}$ and $\mathrm{Bi}$ to partition into the immiscible $\mathrm{CH}_{4}$; these ore metals may have been 
dispersed into the host rocks by the low density $\mathrm{CH}_{4}$ fluid, explaining the presence of anomalous concentrations of $\mathrm{Cu}$ and $\mathrm{Au}$ at great distances (up to $150 \mathrm{~m}$ ) from footwall ores (Hanley 2002). Entrapment of the $\mathrm{P}_{\text {bri- }}$ ne $+\mathrm{PCH} 4$ assemblage could have predated or occurred synchronously with the emplacement of the footwall sulfide veins. As the emplacement of fractionated sulfide liquid into the footwall setting proceeded according to the quantitative models proposed by Naldrett and Pessaran (1992) and Li (1993), sulfides appear to have migrated into the quartz-epidote veins, replacing the earlier-formed silicates. As the sulfides approached their solidus temperature, molten $\mathrm{NaCl}$ and a hydrocarbon fluid may have exsolved from the sulfides, being trapped along secondary fractures in the quartz-epidote veins ( $\mathrm{S}_{\text {halite }}+\mathrm{S}_{\mathrm{CH} 4}$ assemblage). At this stage, $\mathrm{Cu}, \mathrm{PGE}, \mathrm{Au}$ and other metals were extracted from the sulfides by the exsolving volatiles and possibly redeposited as $\mathrm{Pt}-\mathrm{Pd}-$ Te-Bi-Sn minerals, electrum, and disseminated chalcopyrite in the $\mathrm{Cl}$-rich mineral assemblage that now occur along massive sulfide vein margins and in the adjacent host rocks as observed by previous authors (Table 1). The final distribution of the PGE and Au in the footwall ores may have been controlled by the halide melthydrocarbon exsolution, but the molten $\mathrm{NaCl}$ could have only persisted to temperatures as low as $\sim 700^{\circ} \mathrm{C}$ (Fig. 9). Therefore, successive cooling and reequilibration of the ore mineral assemblage along the vein margins would be required to recrystallize the PGE minerals to the lower temperature assemblages observed today $\left(<600^{\circ} \mathrm{C}\right.$; Table 1$)$.

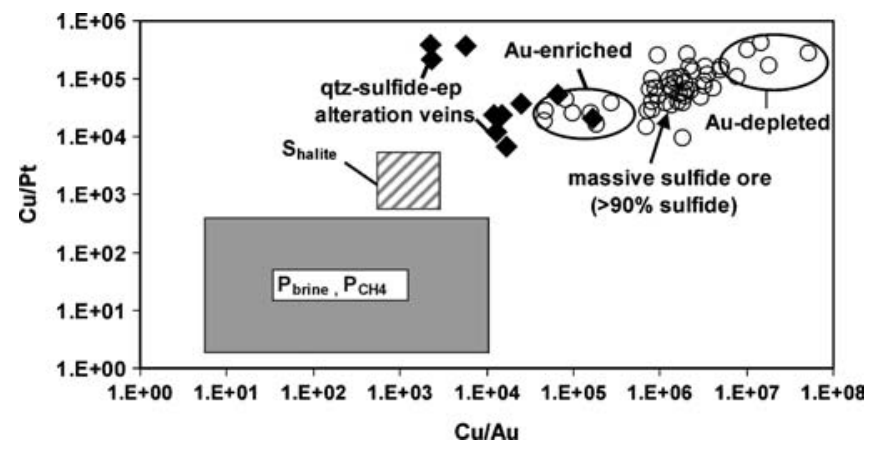

Fig. $15 \mathrm{Log}-\log$ plot of $\mathrm{Cu}: \mathrm{Pt}$ versus $\mathrm{Cu}: \mathrm{Au}$ ratios for massive sulfide ore (Li and Naldrett 1994), quartz-sulfide-epidote alteration veins, primary brine and hydrocarbon inclusions, and halide-melt inclusions. Boxes show range in $\mathrm{Cu}: \mathrm{Au}$ and $\mathrm{Cu}: \mathrm{Pt}$ observed in the volatile-bearing inclusions (Table 1 and Electronic Supplementary Material). $\mathrm{Cu}: \mathrm{Au}$ ratios in massive sulfide samples (open circles) vary over three orders of magnitude and cannot be readily explained using traditional models for sulfide liquid fractionation within the ore zones ( $\mathrm{Li} \mathrm{1993).} \mathrm{Alteration} \mathrm{veins} \mathrm{have} \mathrm{lower} \mathrm{Cu}: \mathrm{Au}$ ratios similar to $\mathrm{Au}$-enriched massive sulfide ores whereas $\mathrm{Cu}: \mathrm{Pt}$ ratios in alteration veins and massive sulfides are comparable. Inclusion compositions (brine-hydrocarbon and halide melt phases) are highly enriched in $\mathrm{Au}$ and $\mathrm{Pt}$ over $\mathrm{Cu}$ when compared to the massive sulfide ores and inclusion-hosting quartz-sulfideepidote veins
Transport of ore metals by volatiles in the footwall environment

The high concentrations of $\mathrm{Cu}, \mathrm{Pt}, \mathrm{Au}, \mathrm{Ag}$ and $\mathrm{Bi}$ observed in the $\mathrm{P}_{\text {brine, }} \mathrm{P}_{\mathrm{CH} 4}$ and $\mathrm{S}_{\text {halite }}$ inclusions confirm previous suggestions (e.g., Farrow 1994) that volatiles were important carriers of ore metals in the Sudbury environment over a wide range of temperatures. It is impossible to evaluate (quantitatively) the importance of the volatiles in modifying the original composition of the sulfide liquids or sulfide ores within the footwall environment; this would require thermochemical data for fluid-sulfide and halide melt-sulfide partitioning behavior and knowledge of the fluid:rock ratios associated with the footwall ore-forming system, which at present are non-existent. However, the data presented here offer some new insight into the behavior of metals in the Sudbury magmatic-hydrothermal environment.

For example, it is interesting to note that $\mathrm{Cu}: \mathrm{Pt}$ and $\mathrm{Cu}: \mathrm{Au}$ ratios in the volatile-bearing inclusions are significantly lower than in the associated massive sulfides and inclusion-hosting alteration veins (Fig. 15). In the halide-melt phase, $\mathrm{Cu}: \mathrm{Au}$ and $\mathrm{Cu}: \mathrm{Pt}$ ratios are $\sim 1-2$ orders of magnitude lower than the suggested parent sulfides; this may reflect the original partitioning behavior of the ore metals between coexisting sulfide and halide melt. The apparent halide melt:sulfide liquid partition coefficient is low for $\mathrm{Cu}$ (e.g., around $\sim 0.02$ based on $\sim 4,500 \mathrm{ppm} \mathrm{Cu}$ in the halide-melt versus $\sim 270,000 \mathrm{ppm} \mathrm{Cu}$ in the massive chalcopyrite-cubanite ore). However, $\mathrm{Pt}$ and $\mathrm{Au}$ concentrations in the halidemelt are comparable to the concentrations within the ores themselves, tentatively suggesting that partition coefficients for $\mathrm{Pt}$ and $\mathrm{Au}$ between sulfide and halidemelt are approximately unity. Consequently, models for magmatic $\mathrm{Ni}-\mathrm{Cu}-\mathrm{PGE}$ ore formation must be revised to consider that volatiles and coexisting sulfide liquids may compete for precious metals during their interaction and may fractionate the precious metals from $\mathrm{Cu}$ at the magmatic-hydrothermal transition.

Similarly, $\mathrm{Au}$ and $\mathrm{Pt}$ concentrations in the brine inclusions are comparable to the ores, but $\mathrm{Cu}: \mathrm{Au}$ and $\mathrm{Cu}: \mathrm{Pt}$ ratios are up to four orders of magnitude lower than the associated sulfides; this observation may reflect the relative solubility behavior of $\mathrm{Cu}$ and $\mathrm{Au}$ (or Pt). In a relatively low $f \mathrm{O}_{2}$ system such as the footwall ore environment, $\mathrm{Au}$ and $\mathrm{Pt}$ solubility in the brine phase may have been enhanced relative to $\mathrm{Cu}$ if the predominant ligand was bisulfide for $\mathrm{Au}$ and $\mathrm{Pt}$ and chloride for $\mathrm{Cu}$. In relatively reduced ore fluids, hydrosaline volatile phases can transport only modest quantities of $\mathrm{Cu}(10$ 100 ppm-range) and the solubility of $\mathrm{Cu}$ as a chloride complex has been shown to decrease with decreasing temperature, chloride concentration and $\mathrm{fO}_{2}$ (Hemley et al. 1992); this observation is consistent with the higher $\mathrm{Cu}$ content of the higher temperature, higher salinity halide melt phase. However, Au solubility by bisulfide or chloride complexation may be significant regardless of the oxidation state of the system and has been shown to 
increase upon cooling due to the transition from chloride complexation to the more soluble bisulphide complex (Gammons and Williams-Jones 1997; Mountain and Seward 1999). On the basis of the composition of alteration assemblages in the footwall environment at Sudbury, Wood (2002) showed that significant Pt transport by chloride was unlikely and that the conditions were more favorable for the transport of precious metals by bisulfide. The possibility of selective metal transport by hydrocarbon-based ligands in the lower temperature volatiles must also be considered and may explain the elevated concentrations of ore metals in the $\mathrm{CH}_{4}$ vapor phase. Recent experimental evidence suggests that organic ligands such as acetate (Wood 2002) and porphyrin compounds (naturally occurring metabolic pigments; Williams-Jones, personal communication) may transport significant concentrations of PGE at hydrothermal conditions. Cooling of the brine, in which $\mathrm{Cu}$ and $\mathrm{Au}$ or $\mathrm{Pt}$ were transported by different ligands with the contrasting solubility behavior described, could lower the $\mathrm{Cu} / \mathrm{Au}$ and $\mathrm{Cu} / \mathrm{Pt}$ ratios in the brine considerably. (Note that $\mathrm{Cu}$ precipitation from a fluid may be indicated by the presence of disseminated chalcopyrite in the adjacent host rocks to the massive sulfide veins). Simple cooling has been shown to lower the $\mathrm{Cu}: \mathrm{Au}$ ratio of ore-forming fluids in other magmatic-hydrothermal deposit types and may be attributed to a similar mechanism (e.g., $\mathrm{Cu}-\mathrm{Au}$ porphyry systems; Ulrich et al. 2001).

\section{Implications for exploration}

During hydrocarbon, brine and halide-melt evolution in the footwall, $\mathrm{Au}$ and $\mathrm{Cu}$ transport and dispersion into the brecciated host rocks may have been substantial. Late-stage hydroxysilicate alteration throughout ore-bearing breccia zones in the footwall deposits confirms that the host rocks to the deposits were relatively fluid-permeable within $\sim 200 \mathrm{~m}$ of ore (Jago et al. 1994; Morrison et al. 1994; Hanley and Mungall 2003; Hanley et al. 2004). Consequently, the occurrence of large hydrocarbon, halogen, or metal enrichment halos around massive sulfide deposits may serve as pathfinders for footwall-style ore deposit at Sudbury and fractionated ore styles in other magmatic $\mathrm{Ni}-\mathrm{Cu}-\mathrm{PGE}$ systems. Notably, $\mathrm{CH}_{4}$ does not occur in significant concentrations in the deep groundwaters along the northern margin of the SIC $(<0.2 \mathrm{vol} \%$; Frape and Fritz 1982) or in brecciated host rocks from unmineralized areas along the northern margin of the SIC (Hanley 2002). If massive sulfide ore bodies are considered to be the sources of hydrocarbon fluids, then bulk analysis of host rocks for their $\mathrm{CH}_{4}$ content may identify important hydrocarbon signatures (e.g., the total abundance of $\mathrm{CH}_{4}$ ) in proximity to mineralization. Gas chromatography of volatiles released during crushing of rock samples offers an inexpensive method for detecting fluid inclusion-hosted hydrocar- bons at extremely low concentrations (Bray and Spooner 1992).

\section{Conclusions}

The results of this study show that $\mathrm{CH}_{4}$ and other hydrocarbon species were important volatile components during the evolution of the footwall-style $\mathrm{Cu}-$ PGE deposits at Sudbury. Of major significance to the origin of the footwall ore systems is the observation that the inclusion assemblages characterized in this study are very rich in $\mathrm{Cu}$ (up to $\sim 1 \mathrm{wt} \%$ ) and contain $\mathrm{Pt}$ and $\mathrm{Au}$ in the ppm-range. Together with high salinity brines and halide melts, hydrocarbons remobilized and dispersed ore metals $(\mathrm{Cu}, \mathrm{Pt}, \mathrm{Au}, \mathrm{Ag}$ and Bi) at least twice during the evolution of the deposits: first, by coexisting (immiscible) metal-rich $\mathrm{CH}_{4}$ and brine during or prior to sulfide emplacement into the footwall setting, and second, by a molten salt phase and hydrocarbon vapor that may have exsolved from the sulfides during their final stage of crystallization. The presence of hydrocarbons coexisting with a high- $T$ halide-melt phase is, as discussed, problematic due to the equilibrium instability of pure hydrocarbon species at such high $T$. Therefore, we admit that the halite inclusions may have been formed by some other process (e.g., precipitated from a halite-saturated hydrocarbon fluid phase at lower $T$ ). The origin of the hydrocarbons coexisting with the $\mathrm{S}_{\text {halite }}$ inclusions is unclear at present and awaits future study.

The interesting partitioning of $\mathrm{Cu}, \mathrm{Au}, \mathrm{Bi}$ and $\mathrm{Ag}$ during early phase separation and mingling of immiscible $\mathrm{CH}_{4}$ and brine is consistent with observations from fluid inclusion boiling assemblages in $\mathrm{Cu}-\mathrm{Au}$ porphyry deposits (e.g., Heinrich et al. 1999; Ulrich et al. 2001) and identifies similar processes operating in two very different magmatic-hydrothermal ore deposit systems. The high concentrations of $\mathrm{Cu}, \mathrm{Pt}, \mathrm{Au}, \mathrm{Ag}$ and $\mathrm{Bi}$ observed in the $\mathrm{P}_{\text {brine, }} \mathrm{P}_{\mathrm{CH} 4}$ and $\mathrm{S}_{\text {halite }}$ inclusions add considerable support to hydrothermal models (e.g., Farrow 1994) for the formation of footwall ore zones at Sudbury and confirm that volatiles were important carriers of ore metals over a wide range of temperatures. Overall, the early unmixing of $\mathrm{CH}_{4}$ and brine, and later exsolution of $\mathrm{H}_{2} \mathrm{O}$-poor volatiles (hydrocarbons, halide melt) from the sulfide ores may have been two principal mechanisms controlling the final distribution of PGE and $\mathrm{Au}$ in the footwall ore systems at Sudbury and may explain the occurrence of distal metal anomalies in orehosting breccia zones, the decoupling of $\mathrm{Au}$ from $\mathrm{S}$ and the PGE, and the occurrence of PGE minerals with Clrich alteration minerals along sulfide vein margins and in adjacent host rocks.

Acknowledgements The authors wish to thank Dave King and Kevin Chisholm (Falconbridge Ltd.) for authorizing access to underground workings at the Fraser Mine and assisting with sample collection. Funding to J. M. from NSERC and PREA 
(Premiere's Research Excellency Awards) was greatly appreciated. Support for J.H. came from an NSERC postgraduate scholarship. The Swiss National Science Foundation is acknowledged for their continued support of the LA-ICP-MS facility at ETH Zurich (Isotope Geology and Mineral Resources). The manuscript was improved through critical reviews by D. Marshall, D. Ebel and L. Meinert and benefited from discussions with B. Sherwood-Lollar and I. Samson.

\section{References}

Atkinson B (2002) A model for the PTZ properties of $\mathrm{H}_{2} \mathrm{O}-\mathrm{NaCl}$. PhD Thesis, Virginia Polytechnic Institute, pp 133

Ballhaus CG, Stumpfl EF (1986) Sulphide and platinum mineralization in the Merensky Reef: evidence from hydrous silicates and fluid inclusions. Contrib Mineral Petrol 94:193-204

Bodnar RJ (1994) Synthetic fluid inclusions; XII, the system $\mathrm{H}_{2} \mathrm{O}-$ $\mathrm{NaCl}$; experimental determination of the halite liquidus and isochores for a $40 \mathrm{wt} \% \mathrm{NaCl}$ solution. Geochim Cosmochim Acta 53:725-733

Bowers TS, Helgeson HC (1983) Calculation of the thermodynamic and geochemical consequences of nonideal mixing in the system $\mathrm{H}_{2} \mathrm{O}-\mathrm{CO}_{2}-\mathrm{NaCl}$ on phase relations in geological systems; equation of state for $\mathrm{H}_{2} \mathrm{O}-\mathrm{CO}_{2}-\mathrm{NaCl}$ fluids at high pressures and temperatures. Geochim Cosmochim Acta 47:1247-1275

Bray CJ, Spooner ETC (1992) Fluid inclusion volatile analysis by gas chromatography with photoionization/micro-thermal conductivity detectors; applications to magmatic $\mathrm{MoS}_{2}$ and other $\mathrm{H}_{2} \mathrm{O}-\mathrm{CO}_{2}$ and $\mathrm{H}_{2} \mathrm{O}-\mathrm{CH}_{4}$ fluids. Geochim Cosmochim Acta 56:261-272

Coats CJA, Snajdr P (1984) Ore deposits of the North Range, Onaping-Levack Area. In: Pye EG, Naldrett AJ, Giblin PE (eds) The geology and ore deposits of the Sudbury structure. Ontario Geological Survey special volume 1:327-346

Cowan JC (1968) Geology of the Strathcona ore deposit. Can Inst Mining Metallurg Bull 61:38-45

Dietz RS (1964) Sudbury structure an Astrobleme. J Geol 72:412434

Dressler BO (1984) The effects of the Sudbury event and the intrusion of the Sudbury Igneous Complex on the Footwall Rocks of the Sudbury structure. In: Pye EG, Naldrett AJ, Giblin PE (eds) The geology and ore deposits of the Sudbury structure. Ontario Geological Survey spec vol 1:97-136

Ebel DS, Naldrett AJ (1997) Crystallization of sulfide liquids and the interpretation of ore composition. Can J Earth Sci 34:352-365

Erwood RJ, Kesler SE, Cloke PL (1979) Compositionally-distinct, saline hydrothermal solutions, Naica Mine, Chihuahua, Mexico. Econ Geol 74:95-108

Farrow CEG (1994) Geology, alteration, and the role of fluids in $\mathrm{Cu}-\mathrm{Ni}-\mathrm{PGE}$ mineralization of the footwall rocks to the Sudbury Igneous Complex, Levack and Morgan Townships, Sudbury District, Ontario. PhD Thesis, Carleton University

Farrow CEG, Lightfoot PC (2002) Sudbury PGE revisited: towards and integrated model. In: Cabri LJ (ed) The geology, geochemistry, mineralogy and mineral beneficiation of platinum-group elements. Canadian Institute of Mining, Metallurgy and Petroleum, Montreal, pp 273-297

Farrow CEG, Watkinson DH (1992) Alteration and the role of fluids in $\mathrm{Ni}, \mathrm{Cu}$ and platinum-group element deposition, Sudbury igneous complex contact, Onaping-Levack Area, Ontario. Mineral Petrol 46:67-83

Frape SK, Fritz P (1982) The chemistry and isotopic composition of saline groundwaters from the Sudbury basin, Ontario. Can J Earth Sci 19:645-661

Frost BR, Touret JLR (1989) Magmatic $\mathrm{CO}_{2}$ and saline melts from the Sybille Monzosyenite, Laramie anorthosite complex, Wyoming. Contrib Mineral Petrol 103:178-186

Gammons CH, Williams-Jones AE (1997) Chemical mobility of gold in the porphyry-epithermal environment. Econ Geol 92:45-59
Goldstein RH (2003) Petrographic analysis of fluid inclusions. In: Samson I, Marshall D, Anderson A (eds) Fluid inclusions: analysis and interpretation. Mineralogical Association of Canada, Short Course Series Vol 32:9-54

Greenman L (1970) The petrology of the footwall breccias in the vicinity of the Strathcona Mine, Levack, Ontario. PhD Thesis, University of Toronto

Grieve RAF (1994) An impact model of the Sudbury structure: proceedings of the Sudbury. In: Lightfoot PC, Naldrett AJ (eds) Proceedings of the Sudbury-Noril'sk symposium. Ontario Geol Surv Spec Vol 5:119-132

Gunther D, Frischknect R, Heinrich CA (1997) Capabilities of a $193 \mathrm{~nm}$ ArF excimer laser for LA-ICP-MS microanalysis of geological materials. J Anal At Spectrom 12:939-944

Hanley JJ (2002) The distribution of the halogens in Sudbury Breccia matrix as as pathfinder elements for footwall $\mathrm{Cu}-\mathrm{PGE}$ mineralization at the Fraser $\mathrm{Cu}$ Zone, Barnet Main Copper Zone, and surrounding margin of the Sudbury Igneous Complex, Onaping-Levack Area, Ontario, Canada. MSc Thesis, University of Toronto

Hanley JJ, Mungall JE (2003) Chlorine enrichment and hydrous alteration of the Sudbury Breccia hosting footwall $\mathrm{Cu}-\mathrm{Ni}-\mathrm{PGE}$ mineralization at the Fraser mine, Sudbury, Ontario, Canada. Can Mineral 41:857-881

Hanley JJ, Mungall JE, Bray CJ, Gorton MP (2004) The origin of bulk and water-soluble $\mathrm{Cl}$ and $\mathrm{Br}$ enrichments in ore-hosting Sudbury Breccia in the Fraser Copper Zone, Strathcona Embayment, Sudbury, Ontario, Canada. Can Mineral 42:17771798

Heinrich CA, Ryan CG, Mernagh TP, Eadington PJ (1992) Segregation of ore metals between magmatic brine and vapor; a fluid inclusion study using PIXE microanalysis. Econ Geol 87:1566-1583

Heinrich CA, Gunther D, Audetat A, Ulrich T, Frischknecht R (1999) Metal fractionation between magmatic brine and vapor, determined by microanalysis of fluid inclusions. Geology 27:755-758

Heinrich CA, Pettke T, and Halter WE (2003) Quantitative multielement analysis of minerals, fluid and melt inclusions by laserablation inductively-coupled-plasma mass-spectrometry. Geochim Cosmochim Acta 67:3473-3497

Hemley JJ, Cygnan GL, Fein JB, Robinson GR, D’Angelo WM (1992) Hydrothermal ore-forming processes in the light of studies in rock-buffered systems: I. $\mathrm{Fe}-\mathrm{Cu} \mathrm{Zn}-\mathrm{Pb}$ sulphide solubility relationships. Econ Geol 87:1-22

Jago BC, Morrison GG, Little TL (1994) Metal zonation patterns and microtextural and micromineralogical evidence for alkaliand halogen-rich fluids in the genesis of the Victor Deep and McCreedy East Footwall Copper Ore bodies, Sudbury Igneous Complex. In: Lightfoot PC, Naldrett AJ (eds) Proceedings of the Sudbury-Noril'sk Symposium. Ontario Geol Surv Spec Vol 5:65-75

Krader T, Franck EU (1987) The ternary systems $\mathrm{H}_{2} \mathrm{O}-\mathrm{CH}_{4}-\mathrm{NaCl}$ and $\mathrm{H}_{2} \mathrm{O}-\mathrm{CH}_{4}-\mathrm{CaCl}_{2}$ to $800 \mathrm{~K}$ and $250 \mathrm{MPa}$. Ber Bunsenges Phys Chem 9:627-634

Krogh TE, Davis DW, Deutch A (1984) Precise U-Pb zircon and baddeleyite ages for the Sudbury Area. In: Pye EG, Naldrett AJ, Giblin PE (eds) The geology and ore deposits of the Sudbury structure. Ontario Geological Survey Special Volume $1: 431-446$

Li C (1993) A quantitative model for the formation of sulfide ores at Sudbury and a tudy on the distributions of platinum-group elements in the Strathcona copper-rich zones, Sudbury, Ontario. PhD Thesis, University of Toronto

Li C, Naldrett AJ (1994) A numerical model for the compositional variations of Sudbury sulfide ores and its application of exploration. Econ Geol 89:1599-1607

Longerich HP, Jackson SE, Gunther D (1996) Laser ablation inductively coupled plasma mass spectrometry transient signal data acquisition and analyte concentration calculation. J Anal Atom Spectrom 11:899-904 
Marshall D, Watkinson D, Farrow CEG, Molnar F, Fouillac AM (1999) Multiple fluid generations in the Sudbury igneous complex: fluid inclusion, $\mathrm{Ar}, \mathrm{O}, \mathrm{H}, \mathrm{Rb}$ and $\mathrm{Sr}$ evidence. Chem Geol 154:1-19

Mathez EA (1987) Carbonaceous matter in mantle xenoliths; composition and relevance to the isotopes. Geochim Cosmochim Acta 51:2339-2347

Mathez EA, Deitrich VJ, Holloway JR, Boudreau AE (1989) Carbon distribution in the Stillwater Complex and evolution of vapor during crystallization of Stillwater and Bushveld magmas. J Petrol 30:153-173

Mavrogenes JA, Berry AJ, Newville M, Sutton SR (2002) Copper speciation in vapor-phase fluid inclusions from the Mole Granite, Australia. Am Mineral 87:1360-1364

Molnar F, Watkinson DH, Jones PC (2001) Multiple hydrothermal processes in footwall units of the North Range, Sudbury igneous complex, Canada, and implications for the genesis of veintype $\mathrm{Cu}-\mathrm{Ni}-\mathrm{PGE}$ deposits. Econ Geol 96:1645-1670

Morrison GG, Jago BC, White TL (1994) Footwall mineralization of the Sudbury Igneous Complex. In: Lightfoot PC, Naldrett AJ (eds) Proceedings of the Sudbury-Noril'sk symposium. Ontario Geol Surv Spec Vol 5:57-64

Mountain BW, Seward TM (1999) The hydrosulphide/sulphide complexes of copper (I); experimental determination of stoichiometry and stability at $22^{\circ} \mathrm{C}$ and reassessment of high temperature data. Geochim Cosmochim Acta 63:11-29

Mungall JE, Brenan JM (2003) Experimental evidence for the chalcophile behaviour of the halogens. Can Mineral 41:207220

Mungall JM, Ames DE, Hanley JH (2004) Geochemical evidence from the Sudbury structure for crustal redistribution by large bolide impacts. Nature 429:546-548

Naden J, Shepherd T (1989) Role of methane and carbon dioxide in gold deposition. Nature 342:793-795

Naldrett AJ, Kullerud G (1967) A study of the Strathcona Mine and its bearing on the origin of the nickel-copper ores of the Sudbury District, Ontario. J Petrol 8:453-531

Naldrett AJ, Pessaran A (1992) Compositional variation in the Sudbury ores and prediction of the proximity of footwall copper-PGE orebodies. In: Milne V (ed) Ontario Geol Survey Misc. Paper 159:47-62

Pettke T, Heinrich CA, Ciocan AC, Gunther D (2004) Quadrupole mass spectrometry and optical emission spectroscopy: detection capabilities and representative sampling of short transient signals from laser-ablation. J Anal Atom Spectrom 9:1149-1155

Pettke T, Diamond LW, Kramers JD (2000) Mesothermal gold lodes in the north-western Alps; a review of genetic constraints from radiogenic isotopes. Eur J Mineral 12:213-230

Poling BE, Prausnitz JM, O'Connell JP (2001) The properties of gases and liquids. McGraw-Hill, New York, pp 752
Potter J, Konnerup-Madsen J (2003) A review of the occurrence and origin of abiogenic hydrocarbons in igneous rocks. In: Petford N, McCaffrey KJW (eds) Hydrocarbons in crystalline rocks. Geological Society of London, Spec Pub 214:151-173

Renders PJ, Seward TM (1989) The stability of hydrosulphido- and sulphido-complexes of $\mathrm{Au}$ (I) and $\mathrm{Ag}$ (I) at $25^{\circ} \mathrm{C}$. Geochim Cosmochim Acta 53:245-253

Renno AD, Leander F, Witzke T, Herzig PM (2004) The coexistence of melts of hydrous copper chloride, sulfide and silicate compositions in a magnesiohastingsite cumulate, TUBAF seamount, Papua New Guinea. Can Mineral 42:1-16

Salvi S, Williams-Jones AE (1992) Reduced orthomagmatic C-O$\mathrm{H}-\mathrm{N}-\mathrm{NaCl}$ fluids in the Strange Lake rare-metal granitic complex, Quebec/Labrador, Canada. Eur J Mineral 4:1155-1174

Salvi S, Williams-Jones AE (1997) Fisher-Tropsch synthesis of hydrocarbons during sub-solidus alteration of the Strange Lake peralkaline granite, Quebec/Labrador, Canada. Geochim Cosmochim Acta 61:83-99

Shepeleva NN, Ogloblina AJ, Pikovskiy YI (1990) Polycyclic aromatic hydrocarbons in Carbonaceous matter of DaldynAlakit area of the Siberian Platform. Geokhimiya 5:731-741

Shock E (1990) Geochemical constraints on the origin of organic compounds in hydrothermal systems. Orig Life Evol Biosph 20:331-367

Sisson VB, Crawford ML, Thompson PH (1981) $\mathrm{CO}_{2}$-brine immiscibility at high temperatures, evidence from calcareous metasedimentary rocks. Contrib Mineral Petrol 78:371-378

Sourirajan S, Kennedy GC (1962) The system NaCl- $\mathrm{H}_{2} \mathrm{O}$ at elevated temperatures and Pressures. Am J Sci 260:115-141

Sugisaki R, Mimura K (1994) Mantle hydrocarbons; abiotite or biotic? Geochim Cosmochim Acta 58:2527-2542

Ulrich T, Gunther D, Heinrich CA (2001) The evolution of a porphyry $\mathrm{Cu}-\mathrm{Au}$ deposit, based on LA-ICP-MS analysis of fluid inclusions; Bajo de la Alumbrera, Argentina. Econ Geol 96:1743-1774

Wood SA (2002) The aqueous geochemistry of the platinum-group elements with applications to ore deposits. In: Cabri LJ (eds) The geology, geochemistry, mineralogy and mineral beneficiation of platinum-group elements. Canadian Institute of Mining Metallurgy and Petroleum, Montreal, pp 211-249

Ypma PJM, Fuzikawa K (1980) Fluid inclusion and oxygen isotope studies of the Nabarlek and Jabiluka uranium deposits, Northern Territory, Australia. In: Ferguson J, Goleby A (eds) Proceedings of the International Uranium symposium on the Pine Creek Geosyncline. Proc Series Intern Atomic Energy Agency 555:375-395

Zhang Y, Franz JD (1987) Determination of the homogenization temperatures and densities of supercritical fluids in the system $\mathrm{NaCl}-\mathrm{KCl}-\mathrm{CaCl}_{2}-\mathrm{H}_{2} \mathrm{O}$ using synthetic fluid inclusions. Chem Geol 64:335-350 